\title{
Shear Behaviour of RC Beams Strengthened by Various Ultrahigh Performance Fibre-Reinforced Concrete Systems
}

\author{
Walid Mansour $\mathbb{D}^{1}$ and Bassam A. Tayeh $\mathbb{D}^{2}$ \\ ${ }^{1}$ Civil Engineering Department, Faculty of Engineering, Kafrelsheikh University, Kafr El-Sheikh, Egypt \\ ${ }^{2}$ Civil Engineering Department, Faculty of Engineering, Islamic University of Gaza, Gaza, State of Palestine \\ Correspondence should be addressed to Bassam A. Tayeh; btayeh@iugaza.edu.ps
}

Received 20 January 2020; Revised 30 March 2020; Accepted 29 June 2020; Published 16 July 2020

Academic Editor: Raffaele Landolfo

Copyright (c) 2020 Walid Mansour and Bassam A. Tayeh. This is an open access article distributed under the Creative Commons Attribution License, which permits unrestricted use, distribution, and reproduction in any medium, provided the original work is properly cited.

\begin{abstract}
This study presents a numerical investigation on the shear behaviour of shear-strengthened reinforced concrete (RC) beams by using various ultrahigh performance fibre-reinforced concrete (UHPFRC) systems. The proposed 3D finite element model (FEM) was verified by comparing its results with those of experimental studies in the literature. The validated numerical model is used to analyse the crucial parameters, which are mainly related to the design of RC beams and shear-strengthened UHPFRC layers, such as the effect of shear span-to-depth ratio on the shear behaviour of the strengthened or nonstrengthened RC beams and the effect of geometry and length of UHPFRC layers. Moreover, the effect of the UHPFRC layers' reinforcement ratio and strengthening of one longitudinal vertical face on the mechanical performance of RC beams strengthened in shear with UHPFRC layers is investigated. Results of the analysed beams show that the shear span-to-depth ratio significantly affects the shear behaviour of not only the normal-strength RC beams but also the RC beams strengthened with UHPFRC layers. However, the effect of shear spanto-depth ratio has not been considered in existing design code equations. Consequently, this study suggests two formulas to estimate the shear strength of normal-strength RC beams and UHPFRC-strengthened RC beams considering the effect of the shear span-to-depth ratio.
\end{abstract}

\section{Introduction}

Many reinforced concrete (RC) structures have to be repaired or strengthened to address their limitations in structural performance and/or durability properties [1]. The need to strengthen can be due to many reasons, such as change in service conditions, corrosion of steel reinforcement, or upgradation of current design code provisions. A promising material used in the strengthening of $\mathrm{RC}$ structures is the ultrahigh performance fibre-reinforced concrete (UHPFRC) because of its superior mechanical properties, very high strength in compression and tension, and extremely densified microstructure. The mechanical properties of UHPFRC have been extensively investigated [2-9].

In the last decade, studies have experimentally used UHPFRC for the flexural strengthening of RC beams
[10-14]. They showed that UHPFRC could increase stiffness and resistance and delay the formation of localised cracks. In addition, Al-Osta et al. [15] explored the effectiveness and efficiency of strengthening RC beams with UHPFRC by (a) roughening the surface of RC beams via sand blasting and casting the UHPFRC in situ around the beams and (b) joining the prefabricated UHPFRC plates to the RC beams using epoxy. However, Tayeh et al. [16] investigated the strengthening of RC beams with UHPFRC laminates using the two different bonding methods of gluing with epoxy and mechanical anchoring. The aforementioned techniques emphasised that beams strengthened with a three-side jacket showed the highest capacity enhancement, whereas beams strengthened only at the bottom soffit showed lower enhancement $[15,16]$. Moreover, the flexural response of strengthened RC beams improved when reinforcing bars were added within the laminates. 
The technique of flexural strengthening using UHPFRC was investigated numerically in [17] by developing a numerical model for the extensive investigation of strengthened RC beams with layers and jackets. Their findings were compared with those of beams strengthened with conventional RC layers and combinations of UHPFRC and steelreinforcing bars. Their results clearly showed that superior performance could be achieved by using the three-side UHPFRC jackets.

Shear failure is unfavourable for engineers because of its sudden occurrence with a brittle failure mode, and many studies have focused on improving the capacity and ductility of RC beams strengthened in shear with UHPFRC [13, 18-22]. Sakr et al. [23] proposed a 3D finite element model (FEM) to investigate the behaviour of RC beams strengthened in shear with prefabricated UHPFRC plates by using (a) one longitudinal vertical-side strengthening and (b) two longitudinal vertical-side strengthening. They concluded that the prefabricated UHPFRC plates could significantly enhance the ultimate load carrying capacity, ductility, and strain of longitudinal reinforcement in the strengthened RC beams compared with the control beam failed in shear.

Moreover, Mohammed et al. [24] experimentally and numerically examined the effectiveness and efficiency of UHPFRC-strengthened RC beam specimens without stirrups by using three different strengthening techniques under torsional moment. The beam specimen strengthened on all four sides obtained higher torsional strength compared with the reference specimen.

Despite the results of these studies using UHPFRC in strengthening and rehabilitating conventional RC beams, limited studies have considered the effect of the shear spanto-depth and UHPFRC layer reinforcement ratios on the behaviour of RC beams strengthened in shear with UHPFRC. Moreover, information on the effect of UHPFRC layer length and geometry on the behaviour of the considered structure is lacking. Because of the difficulty of strengthening many structural elements on both sides especially in exterior beams due to the neighbouring borders, strengthening the RC beams using only one vertical longitudinal side has been considered in the current research. Strengthening only one vertical longitudinal side of the RC beams is rarely studied and evaluated in the literature.

Thus, a 3D FEM with the ability to simulate the behaviour of RC beams strengthened in shear with UHPFRC layers is proposed in this study and validated using the experiments available in the literature (Sections 2 and 3). Additionally, the validated FEM is used in Section 4 to demonstrate the effects of the shear span-to-depth ratio, length, and geometry of UHPFRC layers, reinforcing UHPFRC layers and strengthening only one longitudinal vertical side on the behaviour of RC beams strengthened in shear with UHPFRC layers.

\section{Numerical Investigation}

The shear behaviour of simply supported RC beams strengthened with UHPFRC using different strengthening schemes was investigated numerically. The nonlinear finite element analysis software ABAQUS [25] was used to develop a $3 \mathrm{D}$ model simulating the shear behaviour of UHPFRCstrengthened RC beams.

2.1. Elements and Meshing. Normal-strength concrete (NSC) and UHPFRC are modelled using the 3D stress eight-noded linear brick element (C3D8R), as shown in Figure 1. This figure also shows the two-noded linear $3 \mathrm{D}$ truss element (T3D2), which is used to model the steelreinforcing bars and stirrups. This element is suitable for structural members that transmit only axial load.

A mesh size of $40 \mathrm{~mm} \times 40 \mathrm{~mm}$ was suggested to divide the simulated RC beams to fine elements. The proposed fine mesh was required to obtain accurate results consistent with those of the experimental response on the level of failure load and failure pattern.

2.2. Materials. The model of concrete damage plasticity was used to simulate both concrete and UHPFRC although two other models (concrete smeared and brittle cracking) were available in ABAQUS. The model of concrete damage plasticity was used in this study due to its ability in modelling the complex nonlinear properties of concrete and UHPFRC considering the softening behaviour under either compression or tension. This approach can also be used with a rebar to model concrete reinforcement.

The model of concrete damage plasticity assumes that the uniaxial tensile and compressive response of concrete is characterised by damaged plasticity, as illustrated in Figure 2. The damage variables in compression and tension were denoted by $d_{\mathrm{c}}$ and $d_{\mathrm{t}}$, respectively. Such damage variables can take values from 0 (to represent the undamaged material) to 1 (to denote the total loss of strength). In the case of uniaxial tension, the stress-strain response followed a linear elastic relationship until the value of the failure stress, $\sigma_{t o}$, was reached. Beyond the failure stress, the formation of microcracks was represented macroscopically with a softening stress-strain response, which induced strain localisation in the concrete structure. The response was linear under uniaxial compression until the value of the initial yield, $\sigma_{c o}$, was reached. The response in the plastic zone was typically characterised by stress hardening, followed by strain softening beyond the ultimate stress, $\sigma_{\mathrm{cu}}$. Birtel and Mark [26] proposed the following equations to determine the compressive and tensile damage parameters:

(i) Compressive damage parameter $\left(d_{c}\right)$ :

$$
d_{\mathrm{c}}=1-\frac{\sigma_{\mathrm{c}} E_{\mathrm{c}}^{-1}}{\mathcal{E}_{\mathrm{c}}^{\mathrm{pl}}\left(\left(1 / b_{\mathrm{c}}\right)-1\right)+\sigma_{\mathrm{c}} E_{\mathrm{c}}^{-1}} .
$$

(ii) Tensile damage parameter $\left(d_{\mathrm{t}}\right)$ :

$$
d_{\mathrm{t}}=1-\frac{\sigma_{\mathrm{t}} E_{\mathrm{c}}^{-1}}{\varepsilon_{\mathrm{t}}^{\mathrm{pl}}\left(\left(1 / b_{\mathrm{t}}\right)-1\right)+\sigma_{\mathrm{t}} E_{\mathrm{c}}^{-1}},
$$




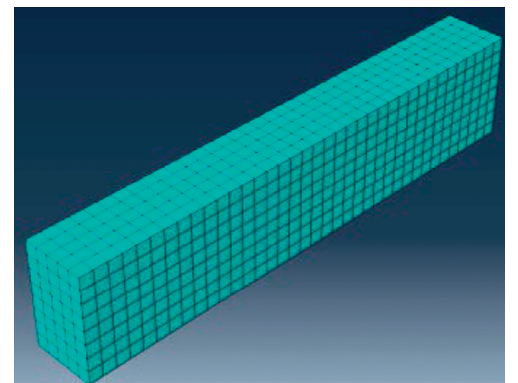

(a)

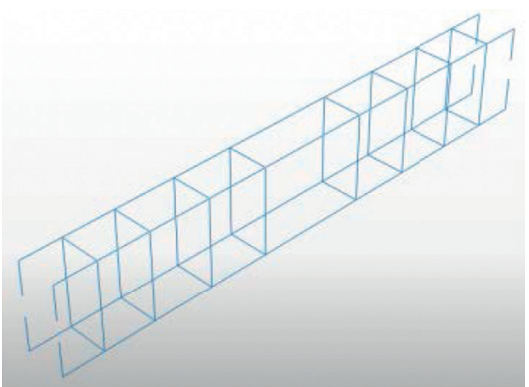

(b)

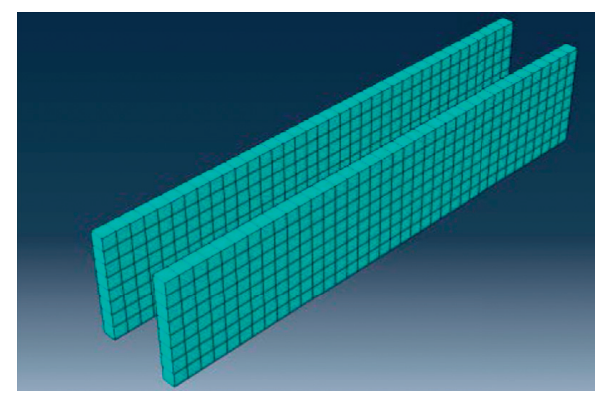

(c)

FIgURE 1: Finite element mesh of beam specimens. (a) Concrete elements. (b) Steel reinforcement elements. (c) UHPFRC elements.

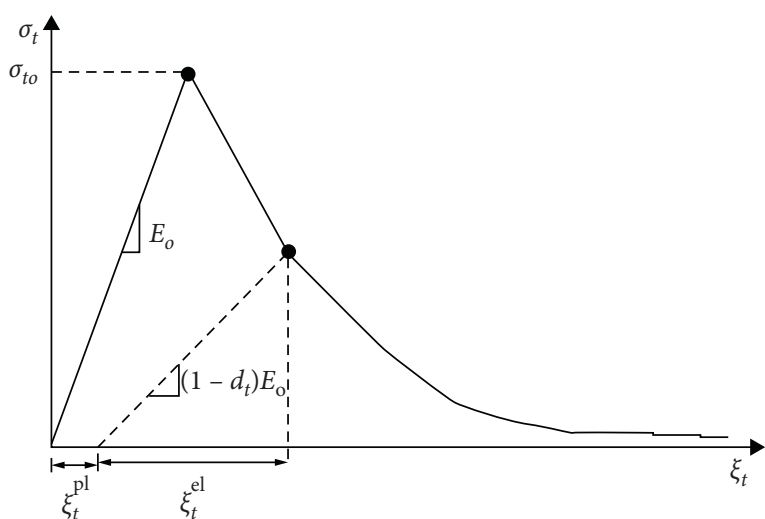

(a)

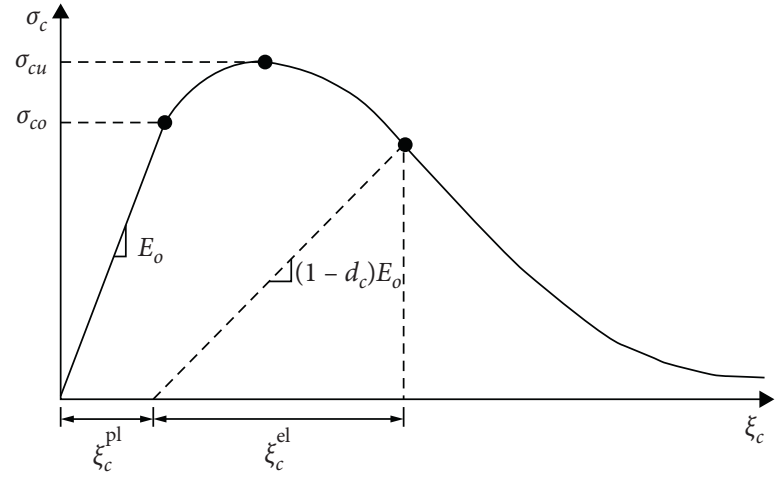

(b)

FIgURE 2: Response of concrete to uniaxial loading in (a) tension and (b) compression [25].

where $d_{\mathrm{c}}$ and $d_{\mathrm{t}}$ are the compressive and tensile damage parameters, respectively; $\sigma_{\mathrm{c}}$ and $\sigma_{\mathrm{t}}$ are the compressive and tensile stresses of concrete, respectively; $E_{\mathrm{c}}$ is the elasticity modulus of concrete; $\varepsilon_{\mathrm{c}}^{\mathrm{pl}}$ and $\varepsilon_{\mathrm{t}}^{\mathrm{pl}}$ are the plastic strains corresponding to the compressive and tensile strengths of concrete, respectively; and $b_{\mathrm{c}}$ and $b_{\mathrm{t}}$ are constant parameters (they can take values from 0 to 1 ).

The reinforcement steel was modelled using elastic-perfectly plastic material, as suggested in [23]. The relationship between the reinforcement steel and concrete was modelled as a perfect bond (embedded region, whereas the concrete was the host element).

\section{Numerical Validation}

The results of the proposed FEM were compared with the experimental results available in the literature [21] to verify its accuracy. The experimental investigation consisted of nine RC beams prepared considering the shear span-todepth ratio $(a / d)$ and strengthening pattern as two variable parameters. Two steel rebars with $20 \mathrm{~mm}$ diameter were placed in the tension zone, whilst two rebars with $12 \mathrm{~mm}$ diameter were provided in the compression zone of all the specimens. Moreover, two-legged stirrups with $8 \mathrm{~mm}$ diameter at a spacing of $120 \mathrm{~mm}$ were used as shear reinforcement. Table 1 lists the details of the nine beam specimens. This table concluded that the beam specimens were strengthened by applying a $30 \mathrm{~mm}$ layer of UHPFRC over the longitudinal vertical faces of the RC beam specimens. UHPFRC jacketing was executed in the following schemes: (a) two longitudinal vertical faces of the beams and (b) two longitudinal vertical faces in addition to the bottom face.

The materials of concrete, UHPFRC, and steel reinforcement were modelled using the data generated through the experimental program, as shown in Table 2.

The model parameters of concrete damage plasticity for concrete and UHPFRC materials are defined in Table 3, whereas the simulated nonlinear properties of both concrete and UHPFRC under tension and compression are depicted in Figure 3.

Table 4 shows the number of elements, number of degrees of freedom, and central processing unit time. The processor type used for this study was $2.4 \mathrm{GHz}$ with core i7.

The bond between NSC and UHPFRC was considered a perfect bond (tie constraint; the concrete and UHPFRC are the master and slave surfaces, respectively) because debonding was not observed in all the experimental tests [27-32]. The control and strengthened beam specimens were analysed under a four-point loading arrangement. All experimental results, including failure load, failure mode, and load-deflection responses, were compared with those obtained through numerical modelling to check their validity. 
TABLE 1: Details of the beam specimens tested by Bahraq et al. [21].

\begin{tabular}{|c|c|c|c|c|}
\hline Beam ID & Strengthening pattern & Dimensions $(b \times h \times L)(\mathrm{mm})$ & a/d ratio & Shear span $(\mathrm{mm})$ \\
\hline CT-1.0 & Control beam & $140 \times 230 \times 1120$ & 1.0 & 200 \\
\hline SB-2SJ-1.0 & Two longitudinal vertical faces & $200 \times 230 \times 1120$ & 1.0 & 200 \\
\hline SB-3SJ-1.0 & Jacket (two longitudinal vertical faces and the bottom face) & $200 \times 260 \times 1120$ & 1.0 & 200 \\
\hline CT-1.5 & Control beam & $140 \times 230 \times 1120$ & 1.5 & 280 \\
\hline SB-2SJ-1.5 & Two longitudinal vertical faces & $200 \times 230 \times 1120$ & 1.5 & 280 \\
\hline SB-3SJ-1.5 & Jacket (two longitudinal vertical faces and the bottom face) & $200 \times 260 \times 1120$ & 1.5 & 280 \\
\hline CT-2.0 & Control beam & $140 \times 230 \times 1120$ & 2.0 & 384 \\
\hline SB-2SJ-2.0 & Two longitudinal vertical faces & $200 \times 230 \times 1120$ & 2.0 & 384 \\
\hline SB-3SJ-2.0 & Jacket (two longitudinal vertical faces and the bottom face) & $200 \times 260 \times 1120$ & 2.0 & 384 \\
\hline
\end{tabular}

TABLE 2: Mechanical properties of concrete, UHPFRC, and shear reinforcement.

\begin{tabular}{lccc}
\hline Property & Concrete & UHPFRC & Shear reinforcement \\
\hline Cubical compressive strength $(\mathrm{MPa})$ & 65 & 151.4 & - \\
Modulus of elasticity (GPa) & 31 & 41 & 200.6 \\
Yield strength (MPa) & - & - & 610 \\
Poisson's ratio & 0.2 & 0.22 & 0.3 \\
\hline
\end{tabular}

TABLE 3: Concrete damage plasticity model parameters for concrete and UHPFRC.

\begin{tabular}{lccccc}
\hline Material & Dilation angle & Eccentricity & $\left(f_{\mathrm{b} 0} / f_{\mathrm{c} 0}\right)$ & $K$ & Viscosity parameter \\
\hline Concrete & 20 & 0.1 & 1.16 & 0.667 & 0 \\
UHPFRC & 36 & 0.1 & 1.16 & 0.667 & 0 \\
\hline
\end{tabular}

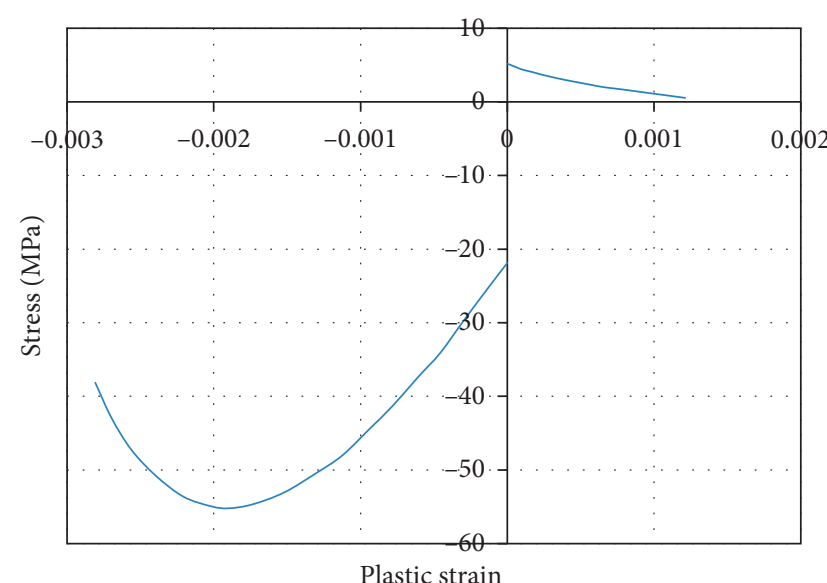

(a)

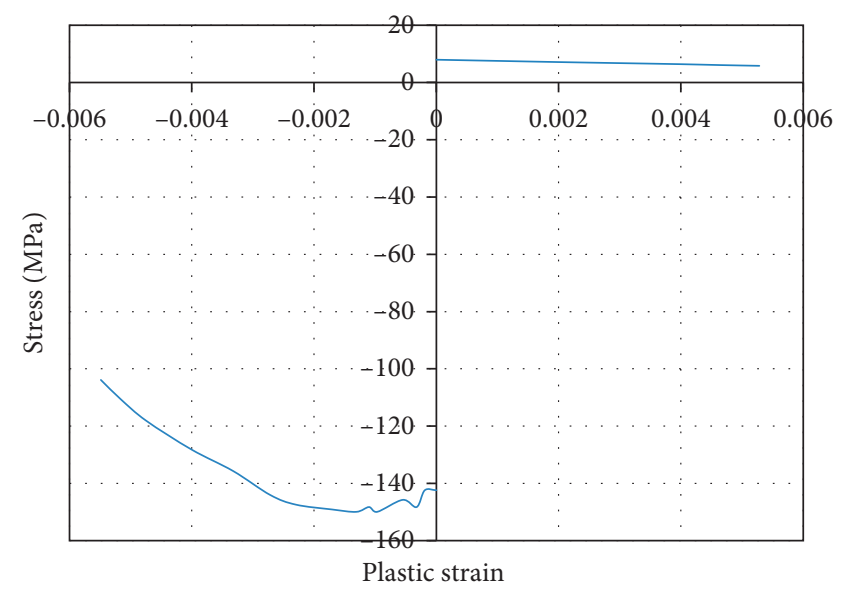

(b)

FIGURE 3: Nonlinear behaviour of materials: (a) concrete and (b) UHPFRC.

TABle 4: Model size and CPU time.

\begin{tabular}{lccc}
\hline Beam ID & Number of elements & Number of degree of freedom (DOF) & CPU time (minutes) \\
\hline CT-1.0 & 5456 & 21000 & 35 \\
SB-2SJ-1.0 & 8016 & 33954 & 55 \\
SB-3SJ-1.0 & 9656 & 40323 & 70 \\
\hline
\end{tabular}

3.1. Load-Deflection Responses. The load-deflection responses of FE obtained for the control beams, beams strengthened using two layers, and beams strengthened using three-side jackets with different shear span-todepth ratios are shown in Figures 4-6, respectively, and compared with the experimental results.
The results showed that FEM could simulate the behaviour of the RC control beams in addition to the RC beams strengthened with UHPFRC with acceptable accuracy.

Table 5 presents a comparison between the experimental results of ultimate load and deflection at maximum load and their counterparts obtained using FE analysis. For the first 
group (control specimens), the experimental value of failure loads for CT-1.0, CT-1.5, and CT-2.0 were 383,286 , and $276 \mathrm{kN}$ versus the predicted 379,295 , and $285 \mathrm{kN}$ through the numerical model with a difference of only $1 \%, 3 \%$, and $3 \%$, respectively. Additionally, FEM could obtain the ultimate load for the strengthened RC beams SB-2SJ-1.0, SB-3SJ-1.0, SB-2SJ-1.5, SB-3SJ-1.5, SB-2SJ-2.0, and SB-3SJ-2.0 with a difference of $1 \%$, $1 \%, 2 \%, 0 \%, 8 \%$, and $1 \%$, respectively, compared with the experimental results, which had acceptable accuracy. The numerical model can accurately estimate not only the ultimate load but also the midspan deflection at maximum load. The experimental midspan deflections for the tested RC beams were in the range of 2.17 to $7.50 \mathrm{~mm}$ compared with 2.70 to $9.00 \mathrm{~mm}$ in the case of FEM.

3.2. Failure Mode. The experimental and numerical investigations showed that control beams CT-1.0, CT-1.5, and CT-2.0 failed in shear compression by forming diagonal cracks joining the points of the load application and support, as shown in Figures 7-9, respectively. In the case of beam specimens SB-2SJ-1.0, SB-2SJ-1.5, and SB$2 \mathrm{SJ}-2.0$, the vertical flexural cracks appeared at the beam midspan, followed by the inclined crack, as depicted in Figures $10-12$, respectively. However, beam specimens SB-3SJ-1.0, SB-3SJ-1.5, and SB-3SJ-2.0 failed in the flexure by forming vertical cracks located in the maximum bending moment zone, as depicted in Figures 13-15, respectively. This comparison concluded that FEM could successfully simulate the majority of failure modes.

\section{Parametric Study}

The validated FEM was used in the numerical investigation of the crucial parameters related to the design of RC beams strengthened in shear with UHPFRC layers. The effect of parameters and the geometry and length of UHPFRC layers on the shear span-to-depth ratio and shear behaviour of RC beams were determined. In addition, the effects of UHPFRC layers' reinforcement ratio and one longitudinal vertical face strengthening on the mechanical performance of RC beams strengthened in shear with UHPFRC layers were demonstrated.

\subsection{Shear Span-to-Depth Ratio}

4.1.1. Control Beam Specimens. Previous studies [33-39] have shown that the shear span-to-depth ratio significantly affects the shear behaviour of RC elements. However, this term has been ignored in current design code equations $[40,41]$, which estimate the shear capacity of RC beams. Eleven normal-strength RC beams with shear span-to-depth ratios ranging from 1.0 to 3.5 at 0.25 intervals were analysed using the validated FEM, as shown in Table 6. Such samples helped not only to understand the performance of RC members with different ratios of shear span-to-depth ratio but also derive an equation estimating the shear capacity of RC beams considering the effect of shear span-to-depth ratio. The

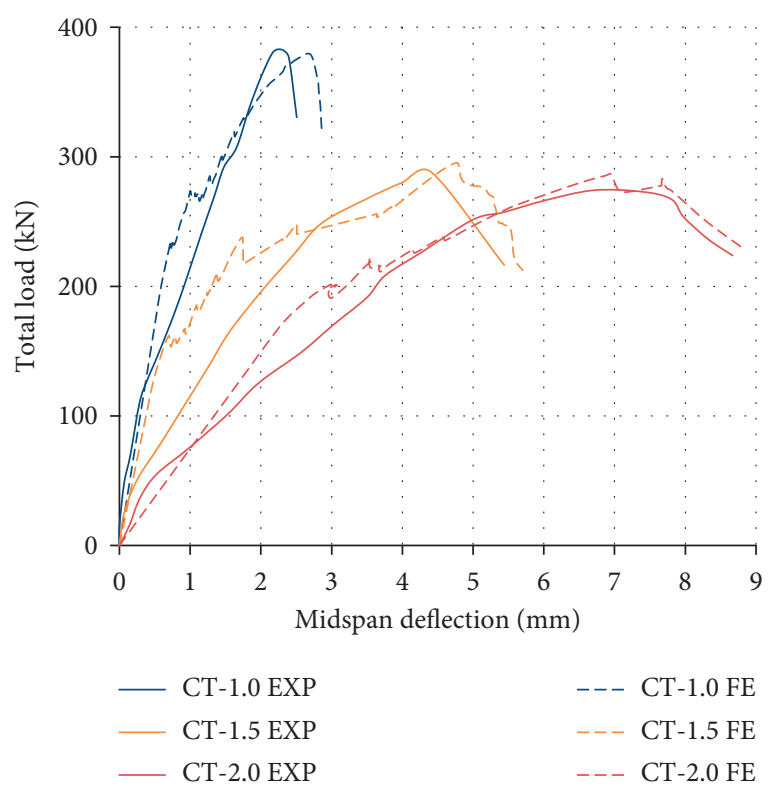

FIgURE 4: Experimental versus FE load-deflection responses for control beam specimens.

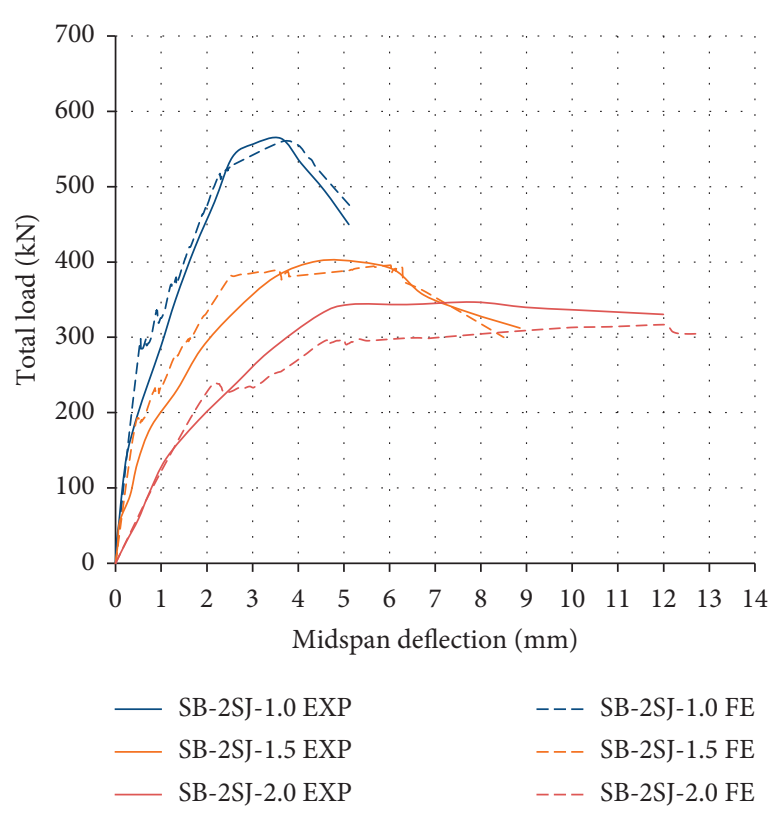

FIgURE 5: Experimental versus FE load-deflection responses for strengthened beam specimens using two vertical layers.

results presented in Table 6 , including the ultimate load besides deflection at ultimate load, reveal that the ultimate load decreases as the shear span-to-depth ratio and deflection increase. As the shear span-to-depth ratio increased, the shear failure mode gradually changed from shear-compression failure to shear-tension failure. Shear cracks propagated rapidly and violently in the sheartension failure, thereby causing the deterioration in ultimate load with the increase in shear span-to-depth ratio. 


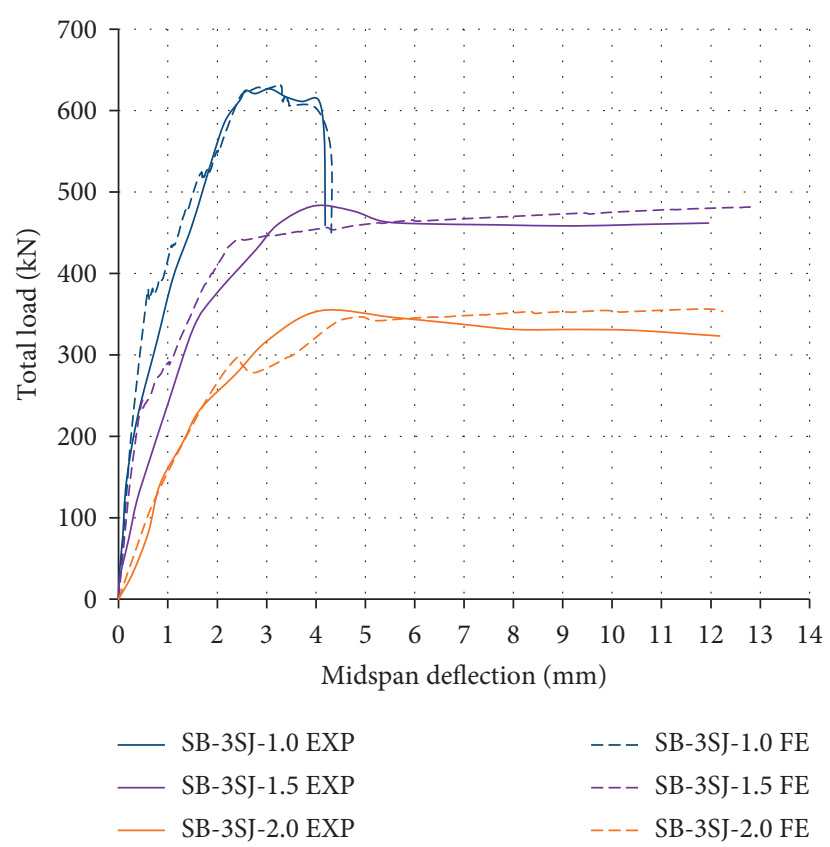

FIGURE 6: Experimental versus FE load-deflection responses for strengthened beam specimens using three-side jacket.

TABLE 5: Summary of the experimental and FE load-deflection responses.

\begin{tabular}{|c|c|c|c|c|}
\hline \multirow{2}{*}{ Beam ID } & \multicolumn{2}{|c|}{ Experimental results } & \multicolumn{2}{|r|}{ FE response } \\
\hline & Ultimate load $(\mathrm{kN})$ & Deflection at ultimate load (mm) & Ultimate load $(\mathrm{kN})$ & Deflection at ultimate load $(\mathrm{mm})$ \\
\hline CT-1.0 & 383 & 2.17 & 379 & 2.70 \\
\hline SB-2SJ-1.0 & 567 & 3.47 & 560 & 3.60 \\
\hline SB-3SJ-1.0 & 628 & 3.10 & 631 & 3.25 \\
\hline CT-1.5 & 286 & 4.40 & 295 & 4.70 \\
\hline SB-2SJ-1.5 & 402 & 5.20 & 396 & 6.00 \\
\hline SB-3SJ-1.5 & 482 & 4.10 & 482 & 6.00 \\
\hline CT-2.0 & 276 & 7.00 & 285 & 6.90 \\
\hline SB-2SJ-2.0 & 346 & 7.50 & 317 & 9.00 \\
\hline SB-3SJ-2.0 & 353 & 4.14 & 356 & 7.20 \\
\hline
\end{tabular}

The ultimate load of the analysed specimens was calculated using the following design codes [40,41].

(1) Euro Code 2 (EC2). The Euro code estimates the shear resistance of beams with stirrups, $V_{r}(N)$, as follows:

$$
\begin{gathered}
V_{r}=0.18 K\left(100 \rho_{\mathrm{l}} f_{\mathrm{c}}\right)^{1 / 3} b d+\frac{A_{s w}}{S} z f_{y w d} \cot \theta_{\mathrm{d}}, \\
\theta_{\mathrm{d}}=\sin ^{-1} \sqrt{\frac{A_{s w} f_{y w d}}{b_{\mathrm{w}} s V_{1} \alpha_{\mathrm{cc}} f_{\mathrm{c}}}},
\end{gathered}
$$

where $K=1+\sqrt{200 / d} \leq 2 ; f_{c}$ is the cylinder compressive strength of concrete, $\mathrm{MPa}$; $d$ is the effective depth, $\mathrm{mm} ; \rho_{\mathrm{l}}$ is the longitudinal reinforcement ratio; $b$ is the beam width, mm; $A_{s w}$ is the cross-sectional area of shear reinforcement; $S$ is the spacing of stirrups; $f_{y w d}$ is the design value of the steel yield strength; and $\theta_{\mathrm{d}}$ is the design concrete strut angle.

The value of $V_{1}$ may be set to $0.9-\left(f_{c} / 200\right)$, whereas the internal lever arm may be set to $z=0.9 d$ [42].
Additionally, the long-term coefficient factor $\alpha_{\text {cc }}$ is set to 0.85 , as recommended in [43].

(2) ACI Code. ACI code considers both the concrete and shear reinforcement contributions when the shear capacity is calculated as

$$
V_{r}=\frac{\sqrt{f_{c}}}{6} b d+\frac{A_{s w}}{S} f_{y w d} d .
$$

The obtained results in numerical ultimate load versus ultimate load using the aforementioned design codes for the 11 specimens are shown in Figure 16.

The EC2 and ACI codes failed to capture the response of the RC beams compared with FEM. Their values are always constant despite the change in shear span-to-depth ratios because this term was ignored in their calculations. Moreover, the ACI code obtained lower estimates than EC2 in the ultimate load of the analysed RC beams because a diagonal concrete strut $\left(\theta_{\mathrm{d}}\right)$ of $45^{\circ}$ was adopted in the ACI model compared with $21.8^{\circ} \leq \theta_{\mathrm{d}} \leq 45^{\circ}$ in the case of the EC2 model. A 


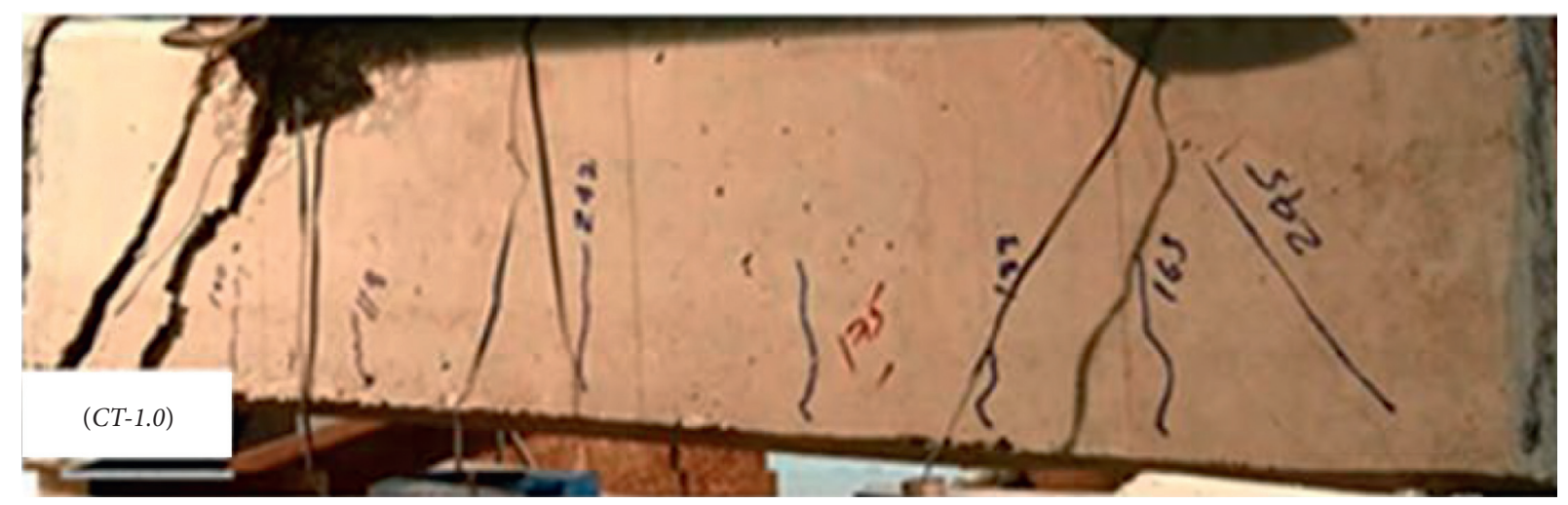

(a)

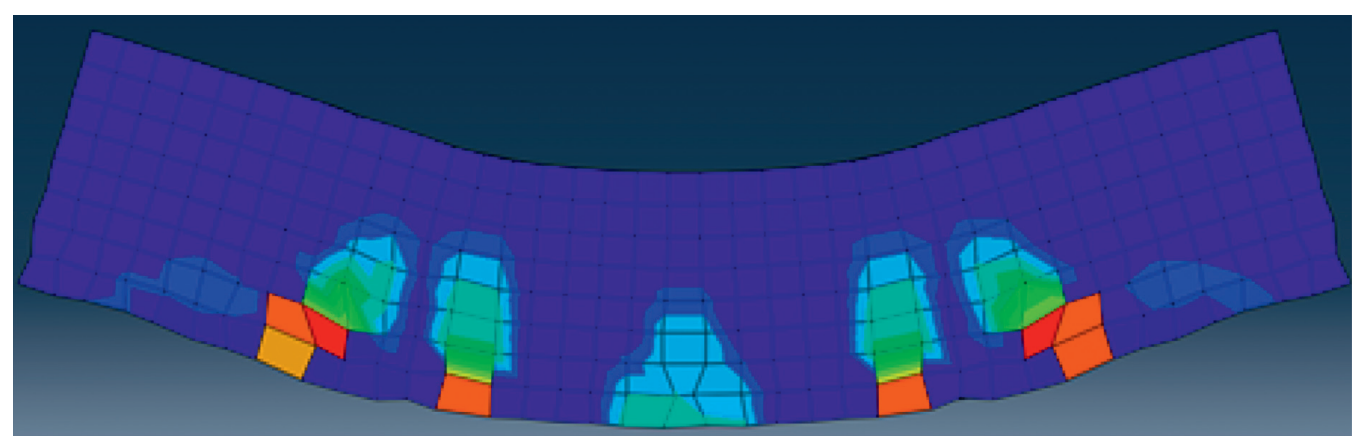

PE, max. principal (avg: $75 \%)$

\begin{aligned} \hline & $+2.191 e-02 \\ & +2.008 e-02 \\ & +1.826 e-02 \\ & +1.643 e-02 \\ & +1.460 e-02 \\ & +1.278 e-02 \\ & +1.095 e-02 \\ & +9.128 e-03 \\ & +7.302 e-03 \\ & +5.477 e-03 \\ & +3.651 e-03 \\ & +1.826 e-03 \\ & +0.000 e+00\end{aligned}$

(b)

FIGURE 7: Failure mode for beam specimen CT-1.0: (a) experiment and (b) FE analysis.

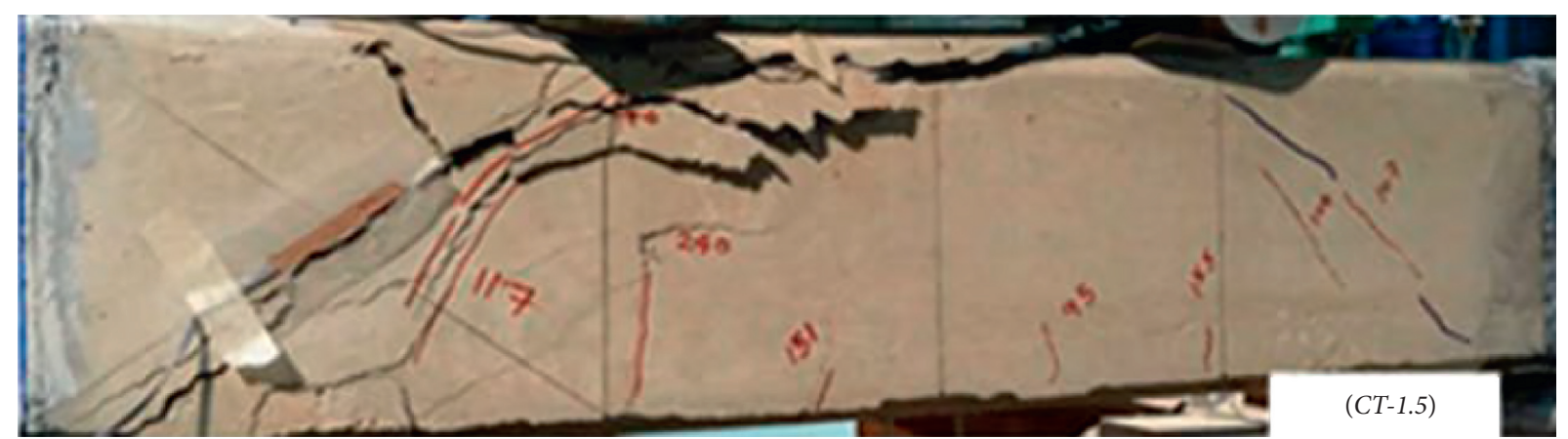

(a)

PE, max. principal (avg: $75 \%$ )
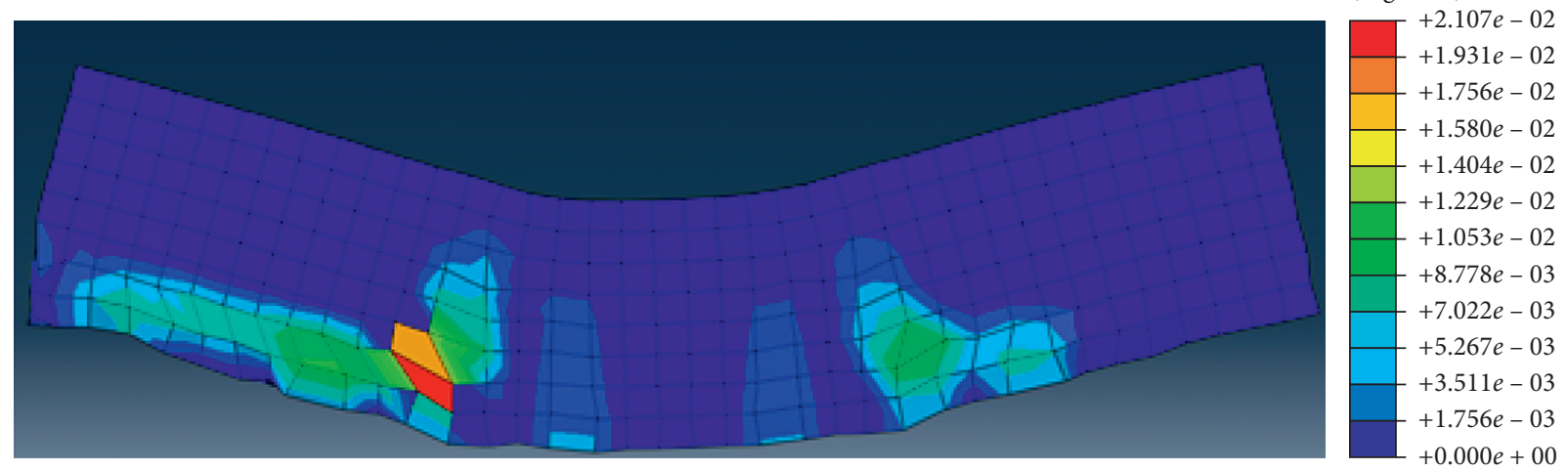

(b)

FIGURE 8: Failure mode for beam specimen CT-1.5: (a) experiment and (b) FE analysis. 


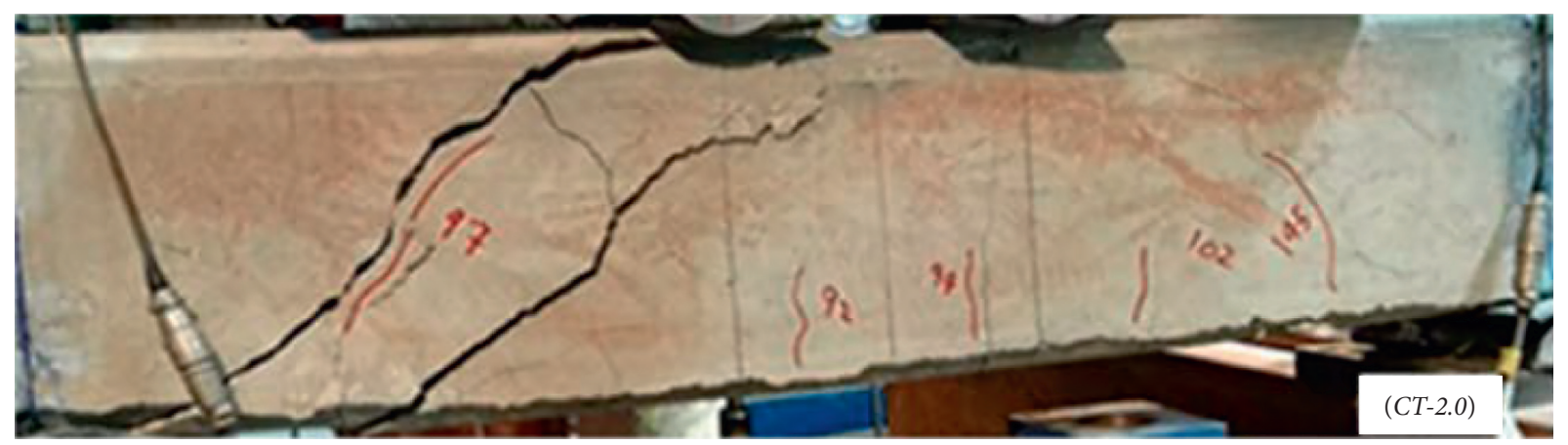

(a)

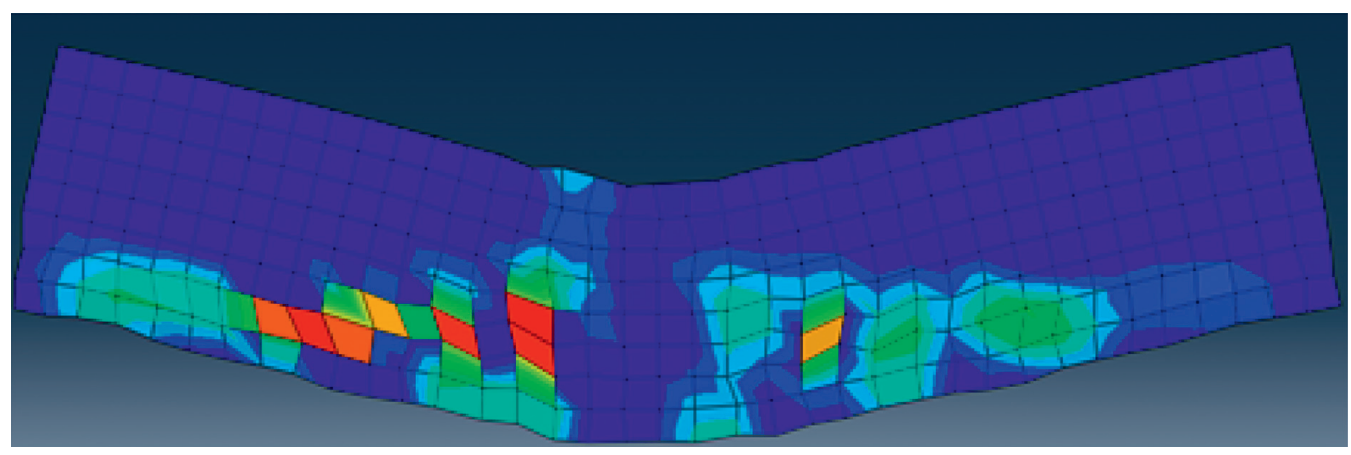

PE, max. principal (avg: $75 \%$ )

$+2.380 e-02$
$+2.181 e-02$
$+1.983 e-02$
$+1.785 e-02$
$+1.586 e-02$
$+1.388 e-02$
$+1.190 e-02$
$+9.915 e-03$
$+7.932 e-03$
$+5.949 e-03$
$+3.966 e-03$
$+1.983 e-03$
$+0.000 e+00$

(b)

Figure 9: Failure mode for beam specimen CT-2.0: (a) experiment and (b) FE analysis.

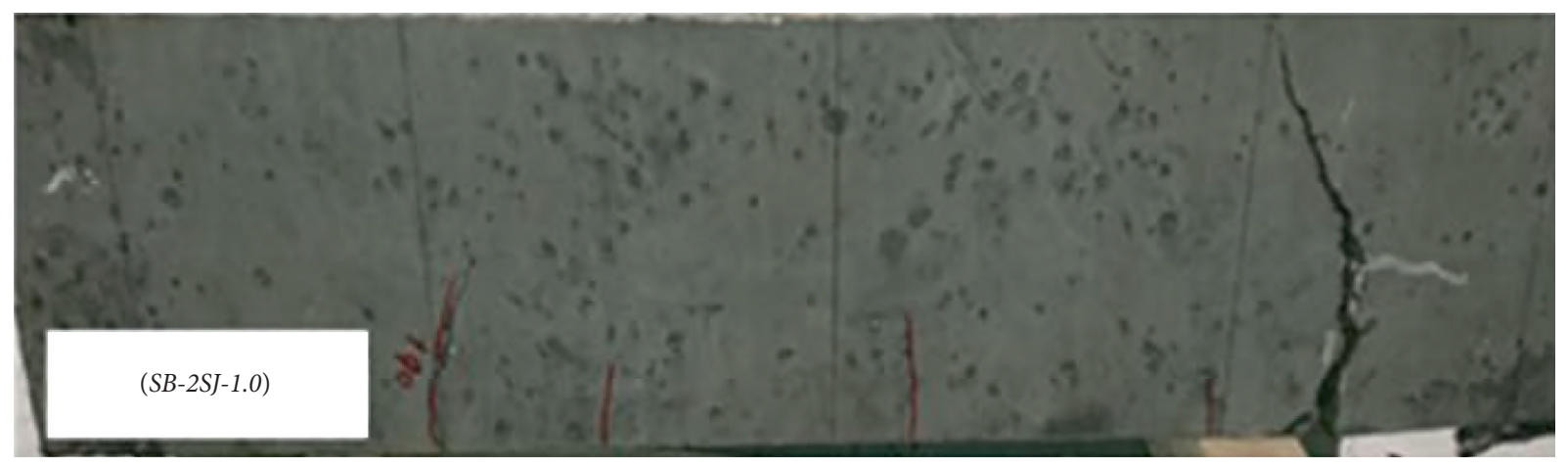

(a)

PE, max. principal (avg: 75\%)
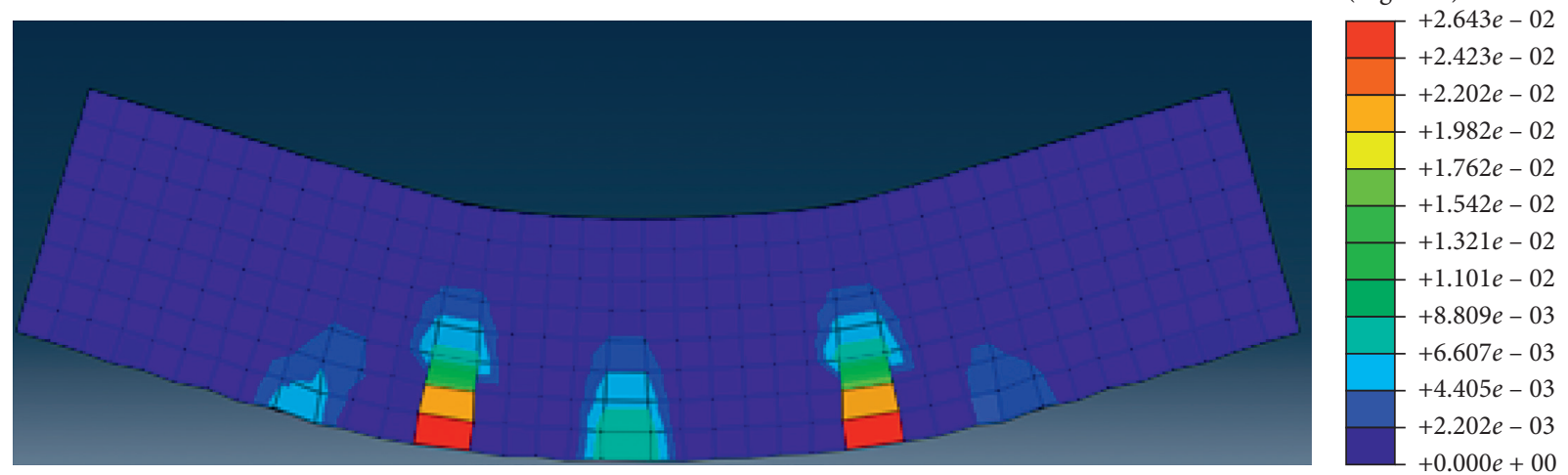

(b)

FIgURE 10: Failure mode for beam specimen SB-2SJ-1.0: (a) experiment and (b) FE analysis. 


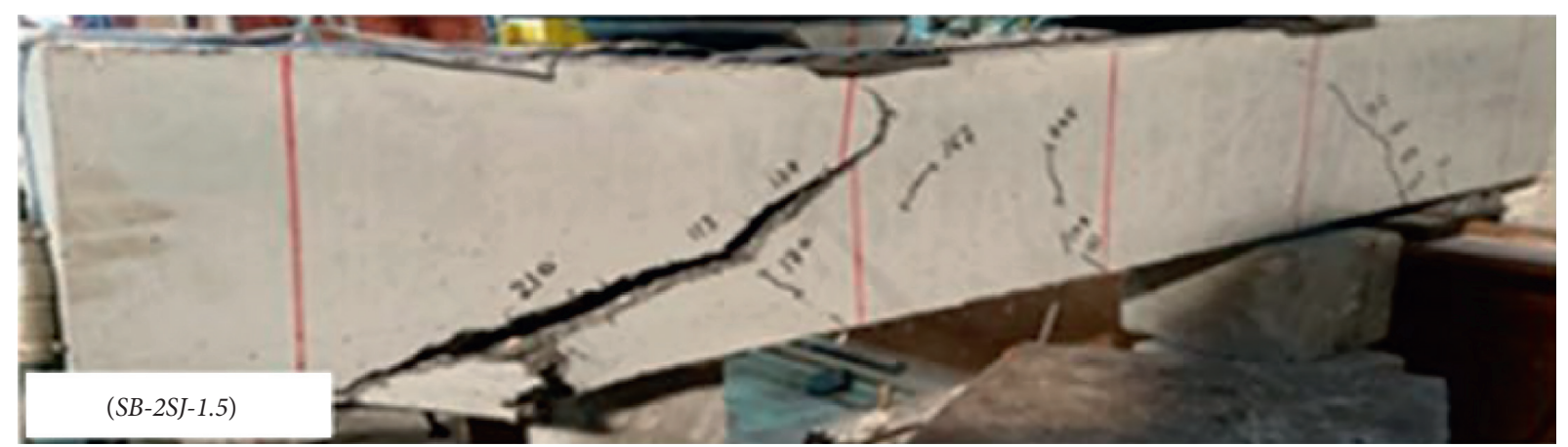

(a)

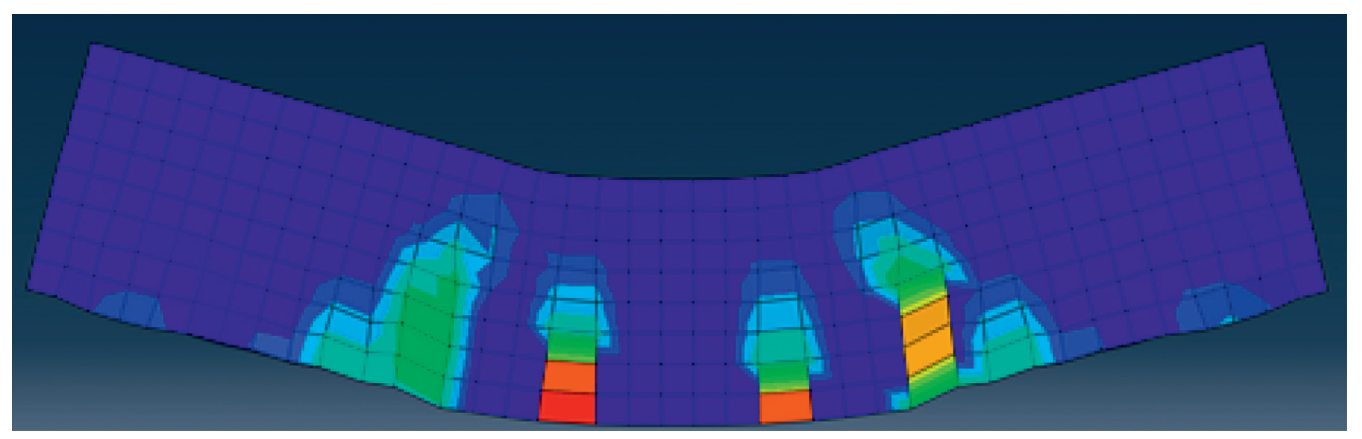

PE, max. principal (avg: 75\%)

$+6.011 e-02$

$+5.510 e-02$ $+5.009 e-02$

$+4.508 e-02$

$+4.008 e-02$

$+3.507 e-02$

$+3.006 e-02$

$+2.505 e-02$

$+2.004 e-02$

$+1.503 e-02$

$+1.002 e-02$

$+5.009 e-03$

(b)

FIgURE 11: Failure mode for beam specimen SB-2SJ-1.5: (a) experiment and (b) FE analysis.

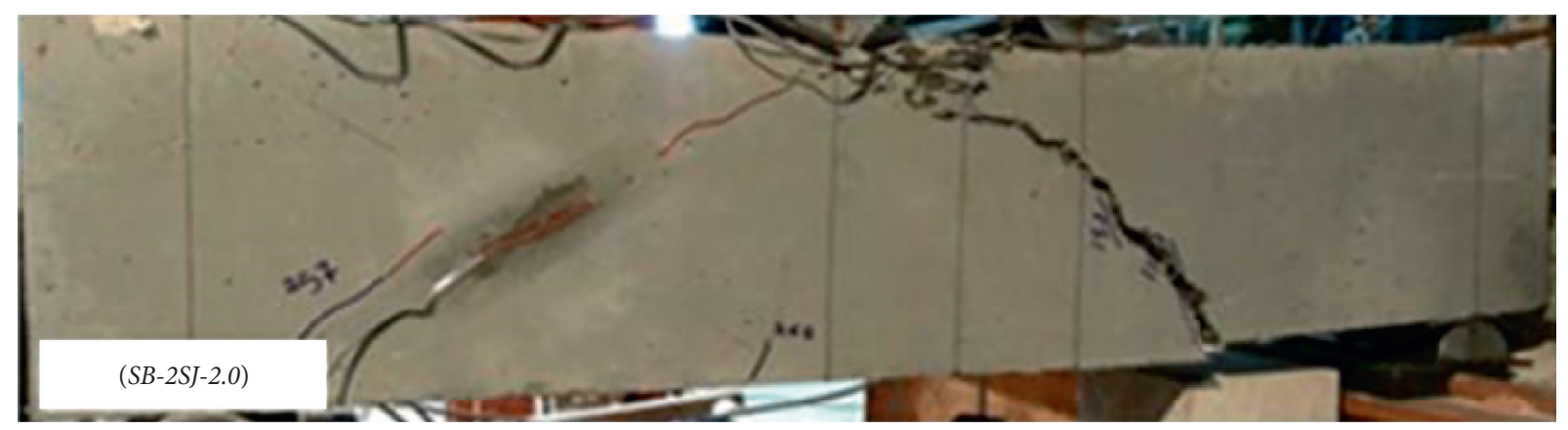

(a)

PE, max. principal (avg: 75\%)
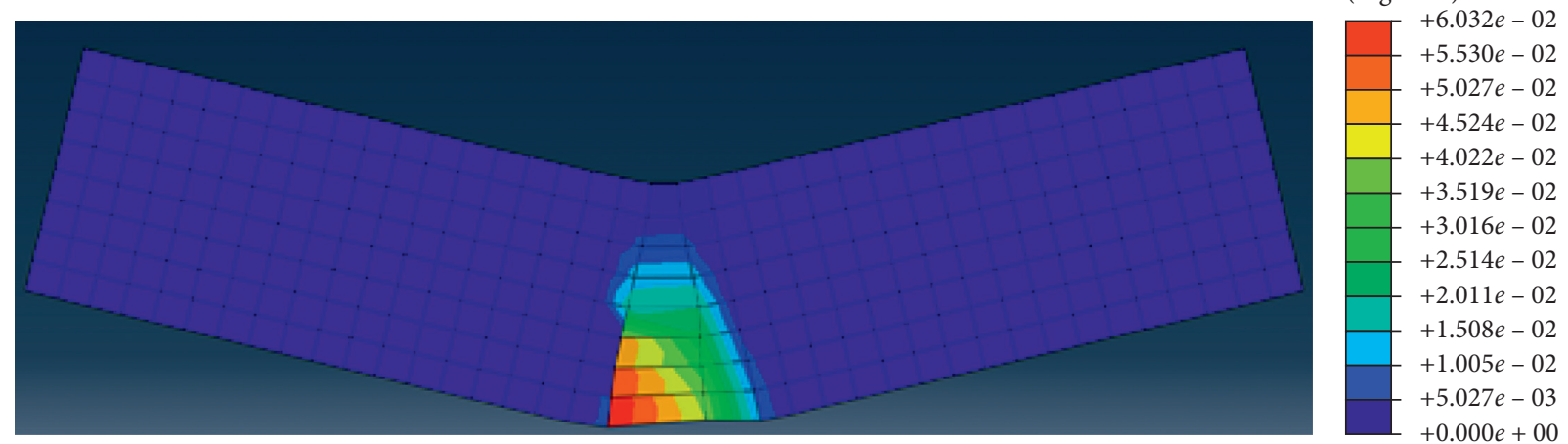

(b)

FIgURE 12: Failure mode for beam specimen SB-2SJ-2.0: (a) experiment and (b) FE analysis. 


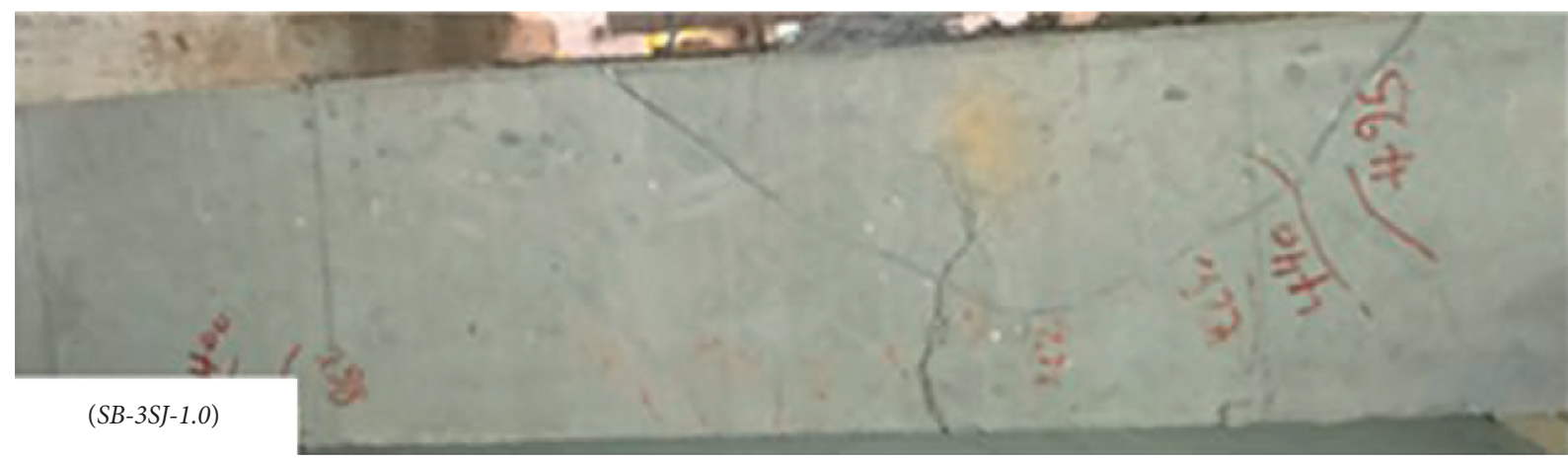

(a)

PE, max. principal (avg: 75\%)
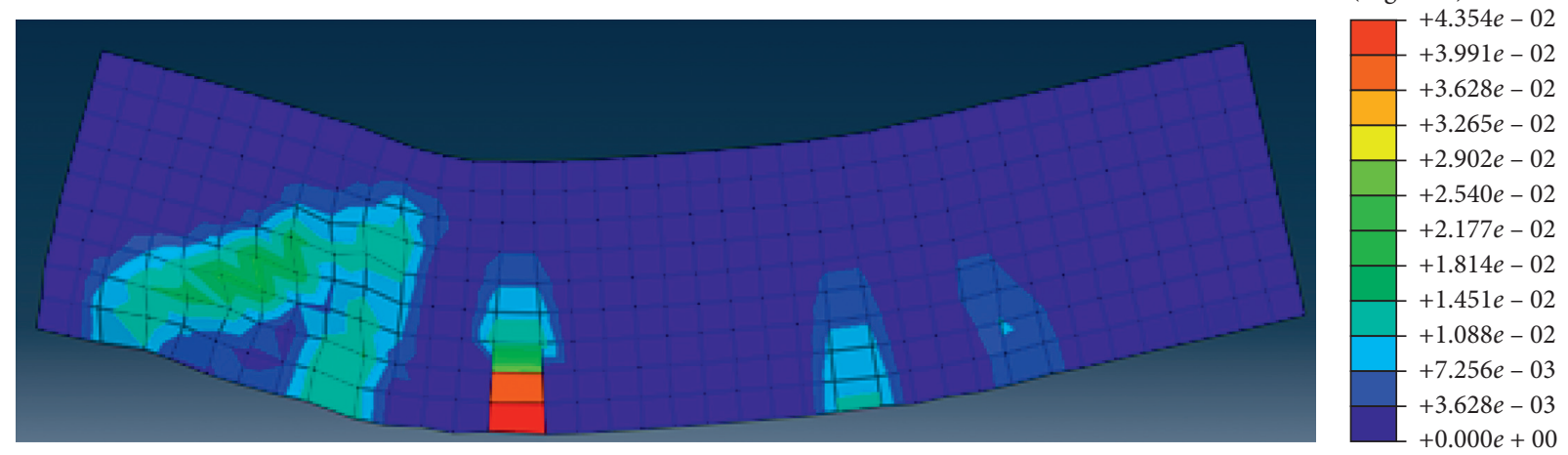

(b)

FIGURE 13: Failure mode for beam specimen SB-3SJ-1.0: (a) experiment and (b) FE analysis.

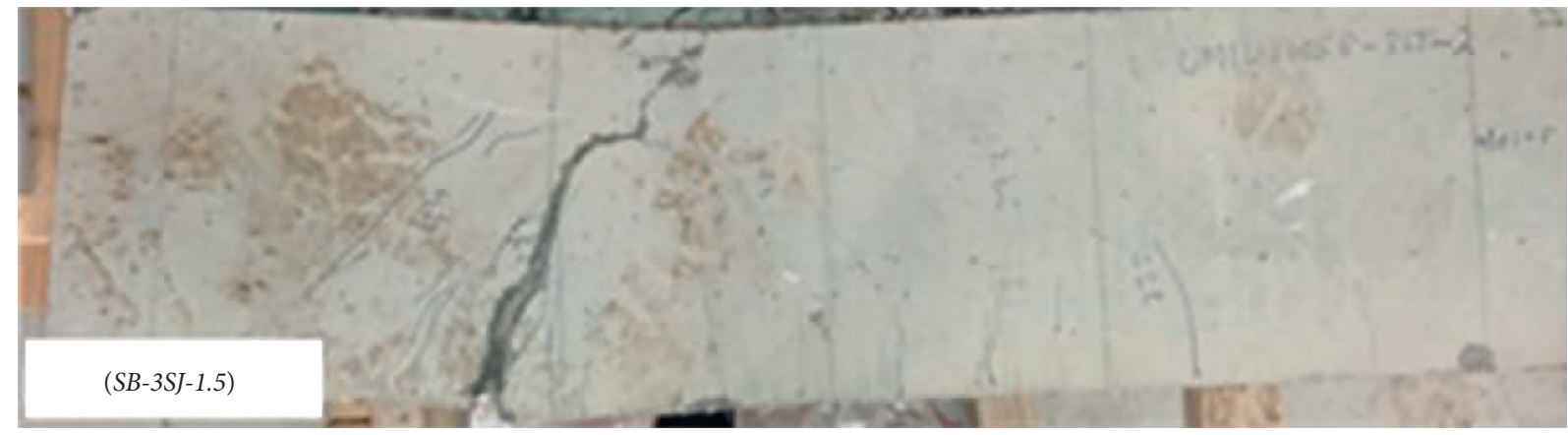

(a)

PE, max. principal (avg: 75\%)
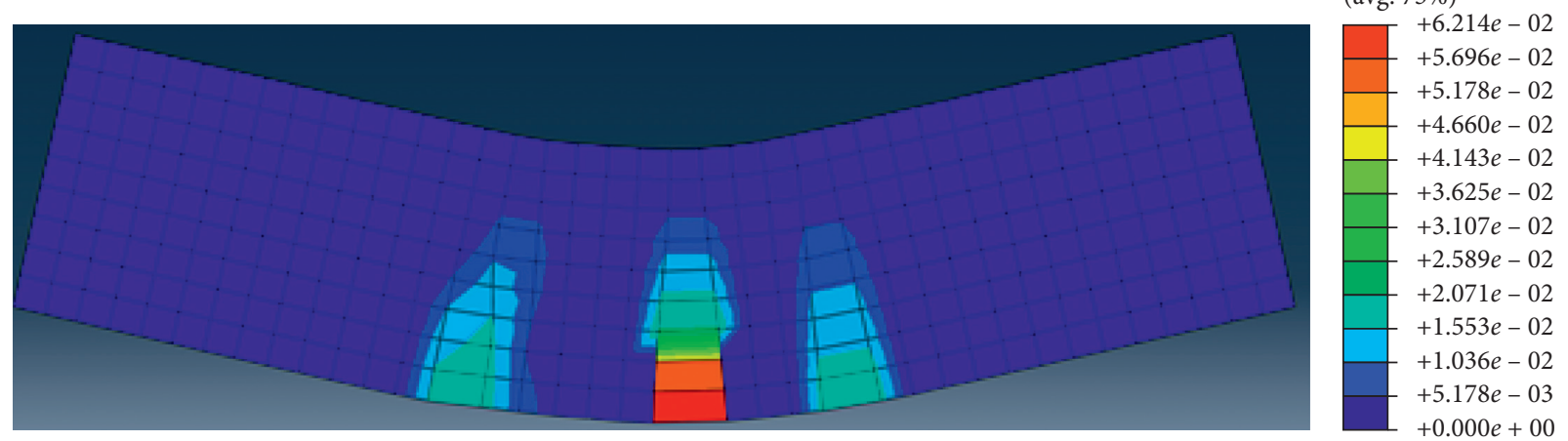

(b)

FIgURE 14: Failure mode for beam specimen SB-3SJ-1.5: (a) experiment and (b) FE analysis. 


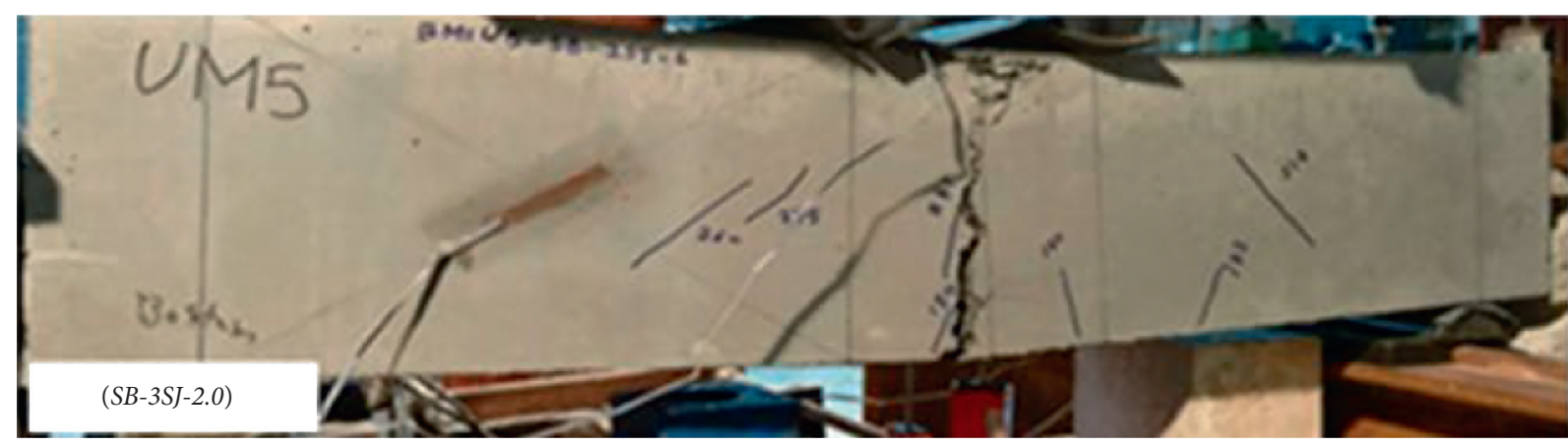

(a)

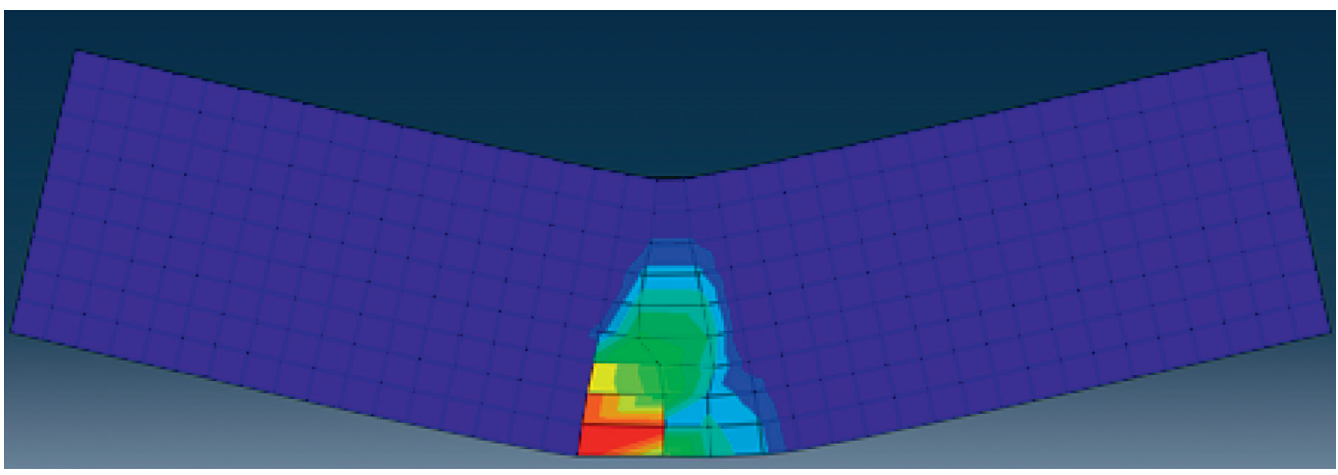

PE, max. principal (avg: $75 \%)$

(b)

FIgURE 15: Failure mode for beam specimen SB-3SJ-2.0: (a) experiment and (b) FE analysis.

TABLE 6: Results of the control beam specimens with various shear span-to-depth ratios.

\begin{tabular}{lcccc}
\hline Beam ID & a/d ratio & Shear span $(\mathrm{mm})$ & Ultimate load $(\mathrm{kN})$ & Deflection at ultimate load $(\mathrm{mm})$ \\
\hline CT- 1.0 & 1.00 & 200 & 379 & 2.70 \\
CT- 1.25 & 1.25 & 250 & 335 & 3.90 \\
CT- 1.5 & 1.50 & 280 & 295 & 4.70 \\
CT- 1.75 & 1.75 & 350 & 289 & 5.90 \\
CT-2.0 & 2.00 & 384 & 285 & 6.90 \\
CT- 2.25 & 2.25 & 450 & 251 & 8.10 \\
CT-2.50 & 2.50 & 500 & 212 & 9.20 \\
CT-2.75 & 2.75 & 550 & 203 & 10.00 \\
CT-3.0 & 3.00 & 600 & 178 & 11.50 \\
CT-3.25 & 3.25 & 650 & 172 & 12.90 \\
CT-3.50 & 3.50 & 700 & 167 & 13.70 \\
\hline
\end{tabular}

new equation that can predict the ultimate load of the $\mathrm{RC}$ beams considering the effect of shear span-to-depth ratio is necessary to improve the accuracy of the current design code equations. A new equation was derived on the basis of nonlinear regression analysis of the numerical results using SPSS statistics program, and its results were compared with those of the numerical and analytical models, as shown in Table 7.

(3) New Equation. The proposed new equation estimates the shear capacity of concrete members considering the concrete compressive strength and effect of shear spanto-depth ratio $(a / d)$ as follows:

$$
V_{c}=1.44 \sqrt{f_{c}}\left(\frac{a}{d}\right)^{-1.208} b d+\frac{A_{s w}}{S} f_{y w d} d
$$

The proposed new equation estimated the ultimate load capacity of RC control beams well by using the numerical model with an average error of $6.34 \%$, as shown in Table 7 . However, further experimental and numerical studies are required to improve the accuracy of the proposed equation.

$$
\text { Error } \%=\frac{\text { FE model }- \text { new equation }}{\text { FE model }} * 100 .
$$




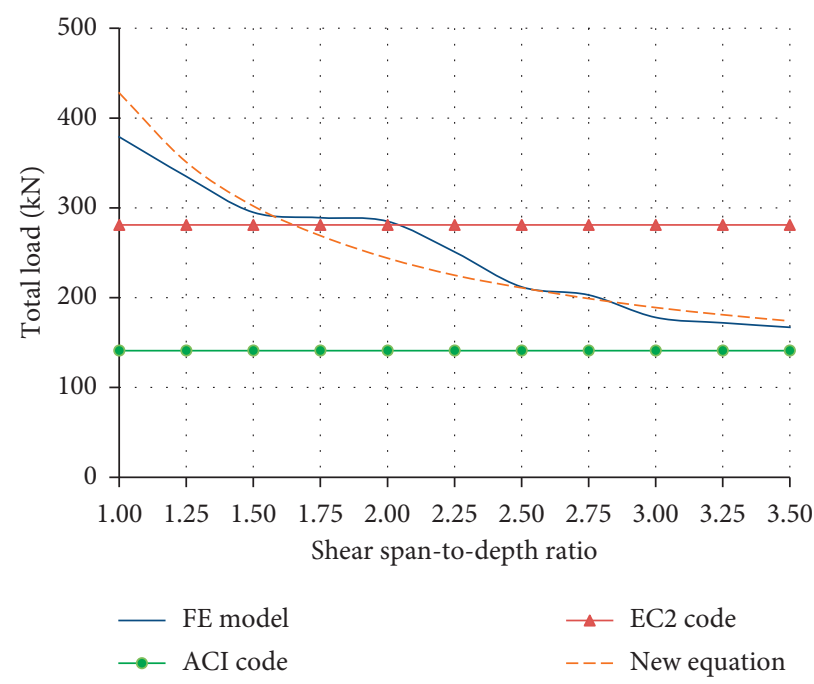

FIGURE 16: Total load capacity for the RC control beams with various shear span-to-depth ratios.

TABLE 7: Results of new equations and numerical and analytical models for the ultimate load of the RC control beams with various shear span-to-depth ratios.

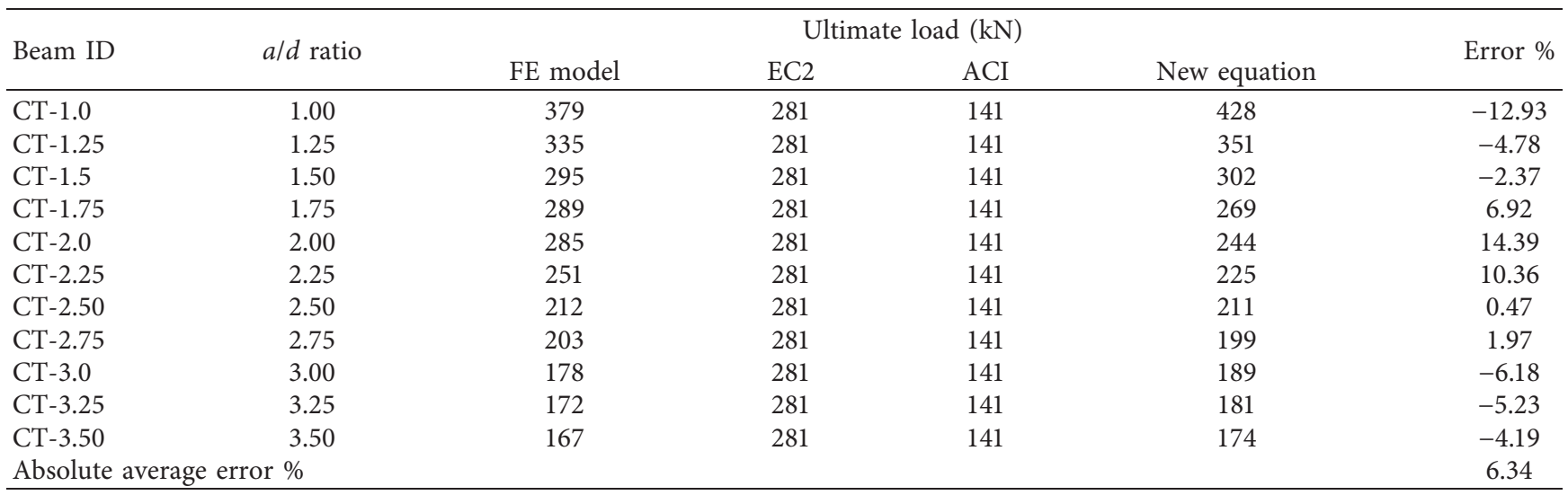

TABLE 8: Results of the RC beam specimens strengthened with UHPFRC with various shear span-to-depth ratios.

\begin{tabular}{lcccc}
\hline Beam ID & ald ratio & Shear span $(\mathrm{mm})$ & Ultimate load $(\mathrm{kN})$ & Deflection at ultimate load $(\mathrm{mm})$ \\
\hline SB-2SJ-1.0 & 1.0 & 200 & 560 & 3.60 \\
SB-2SJ-1.5 & 1.5 & 280 & 396 & 6.00 \\
SB-2SJ-2.0 & 2.0 & 384 & 317 & 9.00 \\
SB-2SJ-2.5 & 2.5 & 500 & 245 & 10.2 \\
SB-2SJ-3.0 & 3.0 & 600 & 200 & 11.3 \\
SB-2SJ-3.5 & 3.5 & 700 & 175 & 13.1 \\
SB-3SJ-1.0 & 1.0 & 200 & 631 & 3.25 \\
SB-3SJ-1.5 & 1.5 & 280 & 482 & 6.00 \\
SB-3SJ-2.0 & 2.0 & 384 & 356 & 7.20 \\
SB-3SJ-2.5 & 2.5 & 500 & 278 & 8.9 \\
SB-3SJ-3.0 & 3.0 & 600 & 226 & 10.1 \\
SB-3SJ-3.5 & 3.5 & 700 & 196 & 11.4 \\
\hline
\end{tabular}

4.1.2. RC Beam Specimens Strengthened with UHPFRC Layers. Table 8 presents the effect of shear span-to-depth ratio on the ultimate load and deflection at the ultimate load of RC beams strengthened with UHPFRC on (a) two longitudinal vertical faces of beams (series SB-2SJ) and (b) two longitudinal vertical faces in addition to the bottom face (series SB-3SJ). The ultimate load of the strengthened RC beams decreased significantly with the increase in shear span-to-depth ratio. In the case of SB-2SJ series, the ultimate load decreased from $560 \mathrm{kN}$ in the case of SB-2SJ-1.0 specimen to $175 \mathrm{kN}$ in the case of SB-2SJ3.5 with a decreasing ratio of $68 \%$. Strengthening the vertical and bottom faces of the RC beams (series SB-3SJ) still 
TABLE 9: Results of the RC beam specimens strengthened with UHPFRC with various lengths with constant shear span-to-depth ratio $=2.0$.

\begin{tabular}{lccc}
\hline Beam ID & Ultimate load $(\mathrm{kN})$ & Ultimate load enhancement $\%$ & Deflection at ultimate load $(\mathrm{mm})$ \\
\hline CT-2.0 & 285 & - & 6.90 \\
SB-2SJ-ST-100 & 299 & 4.90 & 5.25 \\
SB-2SJ-ST-200 & 309 & 8.40 & 8.70 \\
SB-2SJ-0.33L & 287 & 0.70 & 2.40 \\
SB-2SJ-0.74L & 301 & 5.60 & 5.90 \\
SB-2SJ-2.0 & 317 & 11.30 & 9.00 \\
SB-3SJ-ST-100 & 331 & 16.20 & 5.85 \\
SB-3SJ-ST-200 & 348 & 22.20 & 6.95 \\
SB-3SJ-0.33L & 314 & 10.20 & 4.75 \\
SB-3SJ-0.74L & 341 & 19.70 & 6.15 \\
SB-3SJ-2.0 & 356 & 25.00 & 7.20 \\
\hline
\end{tabular}

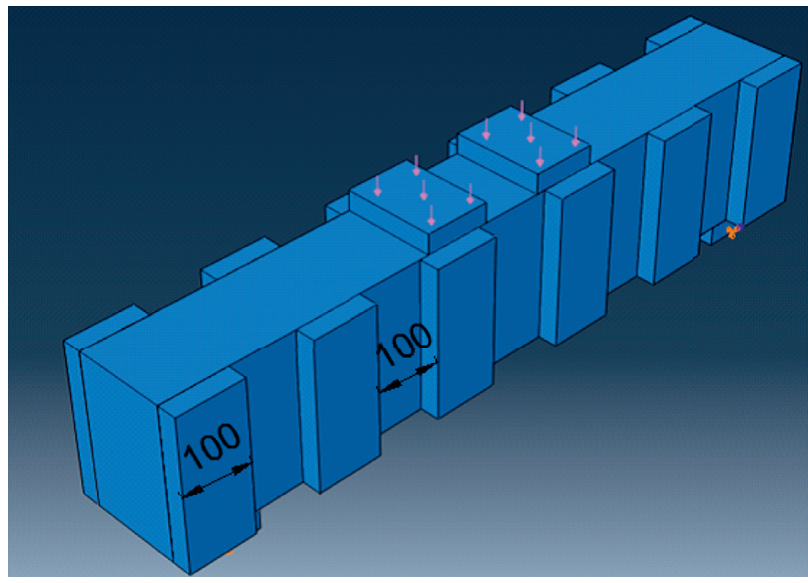

(a)

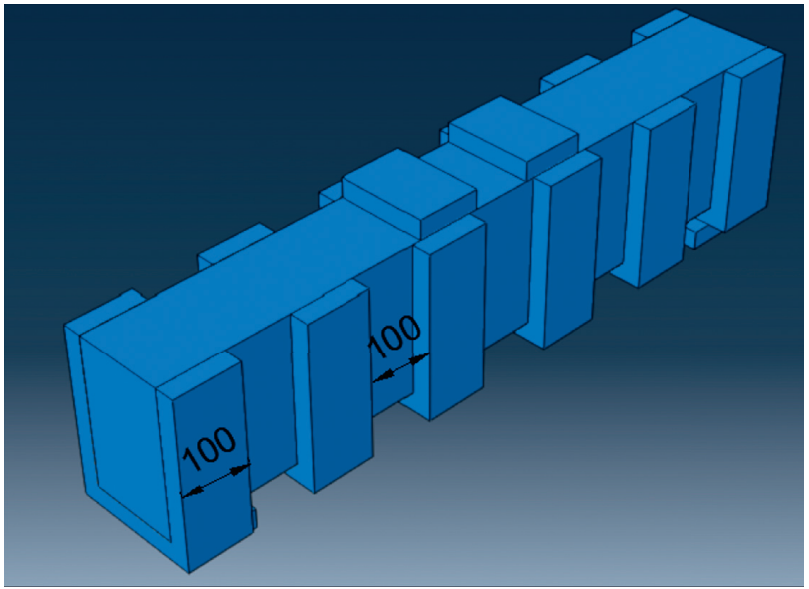

(b)

FIGURE 17: Strengthening configuration: (a) specimen SB-2SJ-ST-100 and (b) specimen SB-3SJ-ST-100 (all dimensions in mm).

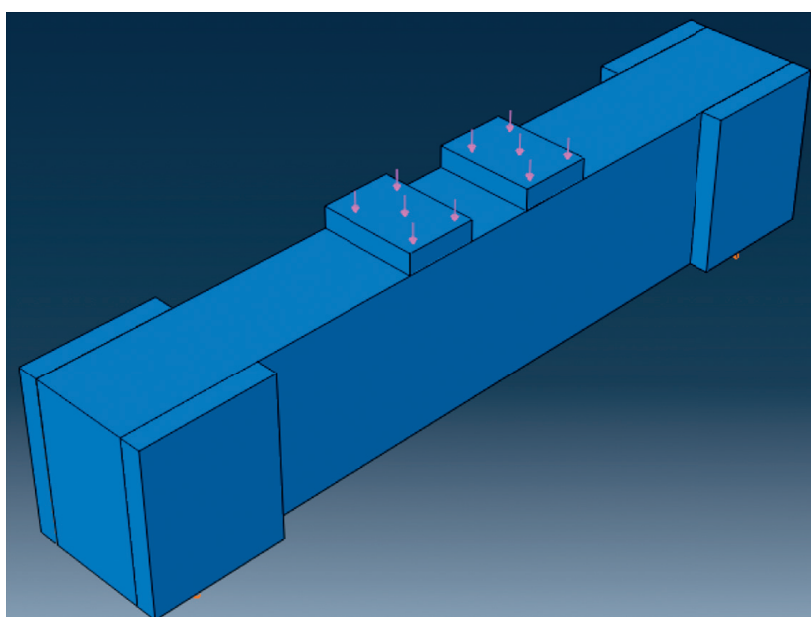

(a)

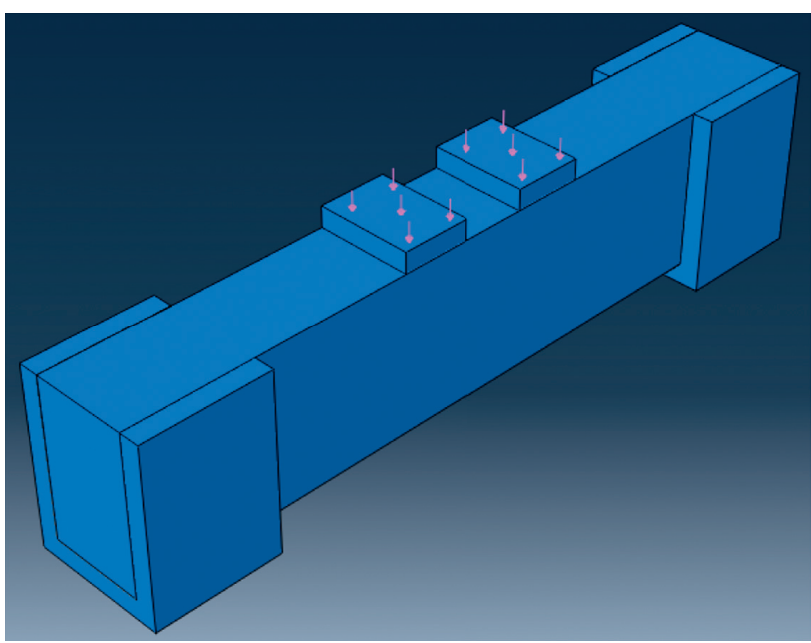

(b)

FIGURE 18: Strengthening configuration: (a) specimen SB-2SJ-0.33L and (b) specimen SB-3SJ-0.33L.

deteriorated the ultimate load with the increase in shear spanto-depth ratio. The ultimate load was $631 \mathrm{kN}$ and $196 \mathrm{kN}$ in the SB-3SJ-1.0 and SB-3SJ-3.5 specimens, respectively, with a decreasing ratio of $69 \%$. By contrast, the shear span-to-depth ratio increased as the deflection at ultimate load increased due to the superior mechanical properties of UHPFRC in tension from the crack bridging phenomena, which occurred because of the presence of steel fibre. 


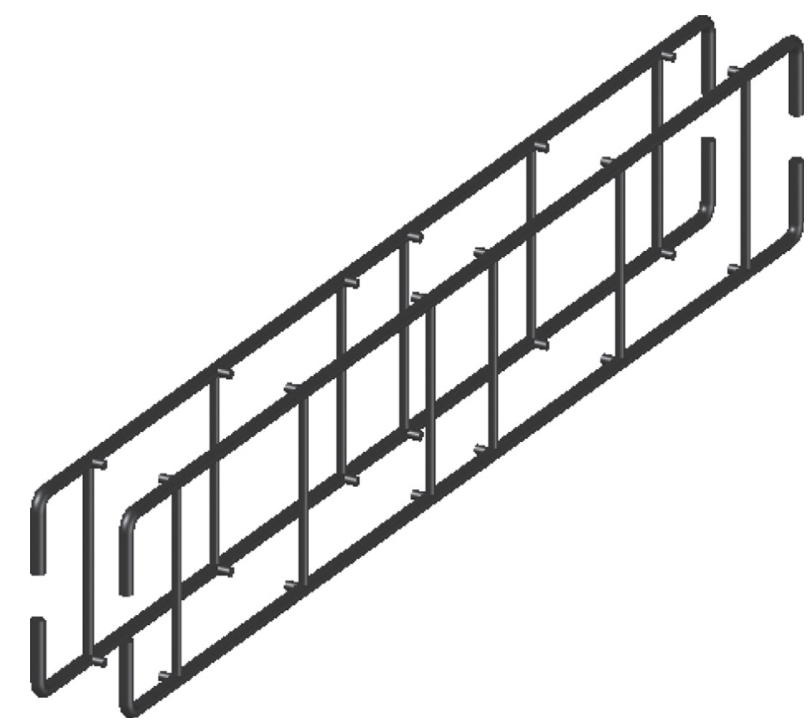

FIGURE 19: Reinforcement assembly embedded in the UHPFRC vertical layers of specimen SB-2SJ-2.3-3.6.

TABLE 10: Results of the RC beam specimens strengthened with reinforced UHPFRC layers with different reinforcement ratios with constant shear span-to-depth ratio $=2.0$.

\begin{tabular}{|c|c|c|c|c|c|c|}
\hline \multirow[t]{2}{*}{ Beam ID } & \multirow[t]{2}{*}{ Shear span $(\mathrm{mm})$} & \multicolumn{2}{|c|}{$\begin{array}{l}\text { Longitudinal reinforcement } \\
\quad\left(\text { ratio }=A_{s} / A_{\text {UHPFRC }} \%\right)\end{array}$} & \multirow{2}{*}{$\begin{array}{c}\text { Transversal reinforcement } \\
\left(\text { ratio }=A_{s t} / A_{\text {UHPFRC }} \%\right) \\
\text { Vertical face }\end{array}$} & \multirow{2}{*}{$\begin{array}{l}\text { Ultimate } \\
\text { load }(\mathrm{kN})\end{array}$} & \multirow{2}{*}{$\begin{array}{c}\text { Deflection at ultimate } \\
\text { load }(\mathrm{mm})\end{array}$} \\
\hline & & Vertical face & Lower face & & & \\
\hline SB-2SJ-2.0 & 384 & - & - & - & 317 & 9.00 \\
\hline SB-2SJ-2.3-3.6 & 384 & $2 \varnothing 10(2.30)$ & - & $5 \varnothing 8 / \mathrm{m}(3.60)$ & 361 & 11.00 \\
\hline SB-2SJ-3.3-3.6 & 384 & $2 \varnothing 12(3.30)$ & - & $5 \varnothing 8 / \mathrm{m}(3.60)$ & 400 & 13.75 \\
\hline SB-2SJ-5.8-3.6 & 384 & $2 \varnothing 16(5.80)$ & - & $5 \varnothing 8 / \mathrm{m}(3.60)$ & 465 & 14.25 \\
\hline SB-2SJ-7.4-3.6 & 384 & $2 \varnothing 18(7.40)$ & - & $5 \varnothing 8 / \mathrm{m}(3.60)$ & 511 & 16.45 \\
\hline SB-2SJ-7.4-5.7 & 384 & $2 \varnothing 18(7.40)$ & & $5 \emptyset 10 / \mathrm{m}(5.70)$ & 515 & 17.20 \\
\hline SB-2SJ-7.4-7.3 & 384 & $2 \varnothing 18(7.40)$ & & $10 \varnothing 8 / \mathrm{m}(7.30)$ & 516 & 17.35 \\
\hline SB-3SJ-2.0 & 384 & - & - & - & 356 & 7.20 \\
\hline SB-3SJ-2.3-2.6 & 384 & $2 \varnothing 10(2.30)$ & $2 \varnothing 10(2.6)$ & $5 \varnothing 8 / \mathrm{m}(3.60)$ & 490 & 9.35 \\
\hline SB-3SJ-3.3-3.8 & 384 & $2 \varnothing 12(3.30)$ & $2 \varnothing 12(3.8)$ & $5 \varnothing 8 / \mathrm{m}(3.60)$ & 560 & 11.70 \\
\hline SB-3SJ-5.8-6.7 & 384 & $2 \emptyset 16(5.80)$ & $2 \varnothing 16(6.70)$ & $5 \varnothing 8 / \mathrm{m}(3.60)$ & 640 & 13.30 \\
\hline SB-3SJ-7.4-8.5 & 384 & $2 \varnothing 18(7.40)$ & $2 \varnothing 18(8.5)$ & $5 \emptyset 8 / \mathrm{m}(3.60)$ & 673 & 14.25 \\
\hline
\end{tabular}

$A_{s}=$ area of longitudinal reinforcement, $A_{s t}=$ area of transversal reinforcement, and $A_{\text {UHPFRC }}=$ area of UHPFRC layer.

4.2. Geometry and Length of UHPFRC Layers. This section investigated the effect of the strengthening pattern and strengthening length on the shear response of the $\mathrm{RC}$ beams strengthened with UHPFRC layers. Ten RC beams were strengthened via (a) strengthening with UHPFRC strips spaced every $100 \mathrm{~mm}$ and (b) strengthening using UHPFRC layers. The results are listed in Table 9. The following nomenclature was used to distinguish between the two technical specimens:

SB-2SJ-ST-100: the specimen strengthened with UHPFRC strips where the third and fourth items were $\mathrm{ST}=$ strips and width of the UHPFRC strip $=100 \mathrm{~mm}$, respectively (Figure 17).

SB-2SJ-0.33L: the specimen strengthened with a UHPFRC layer, where the third item is the length of the UHPFRC layer as a ratio from the beam length $(L)$ and equal to $0.33 \mathrm{~L}$ (Figure 18).
In the RC beams strengthened using two longitudinal vertical faces of UHPFRC, as expected, specimen SB-2SJ-2.0 was fully strengthened over its length and obtained the highest ultimate load and deflection at $317 \mathrm{kN}$ and $9.00 \mathrm{~mm}$, respectively. However, specimen SB-2SJ-0.33L with the lowest strengthening length realised the lowest ultimate load $(287 \mathrm{kN})$ with an increasing ratio equal to only $0.7 \%$, as compared with the reference beam CT-2.0. Additionally, specimen SB-2SJ$0.74 \mathrm{~L}$ (strengthened along the shear zones only) improved the failure load by $5.60 \%$, whereas the control beam CT-2.0 obtained $5.90 \mathrm{~mm}$ deflection at the ultimate load.

In the case of specimens strengthened on both vertical faces and lower face using UHPFRC, the ultimate load capacity increased as the strengthening length increased. Specimen SB-3SJ-2.0 obtained the highest ultimate load and deflection at $356 \mathrm{kN}$ and $7.20 \mathrm{~mm}$, respectively, whereas specimen SB-3SJ-0.33L achieved the lowest ultimate load $(314 \mathrm{kN})$, which was $10.20 \%$ higher than that 
TABLE 11: Results of the RC beam specimens strengthened with one vertical face of reinforced and nonreinforced UHPFRC layer with constant shear span-to-depth ratio $=2.0$.

\begin{tabular}{|c|c|c|c|c|c|}
\hline Beam ID & $\begin{array}{c}\text { Longitudinal reinforcement } \\
\quad\left(\text { ratio }=A_{s} / A_{\text {UHPFRC }} \%\right)\end{array}$ & $\begin{array}{c}\text { Transversal reinforcement } \\
\left(\text { ratio }=A_{s t} / A_{\text {UHPFRC }} \%\right)\end{array}$ & $\begin{array}{c}\text { Ultimate load } \\
(\mathrm{kN})\end{array}$ & $\begin{array}{c}\text { Deflection at ultimate } \\
\text { load }(\mathrm{mm})\end{array}$ & $\begin{array}{c}\text { Stiffness }(\mathrm{kN} / \\
\mathrm{mm})\end{array}$ \\
\hline CT-2.0 & - & - & 285 & 6.90 & 75 \\
\hline $\begin{array}{l}\text { SB-1SJ- } \\
\text { ST-100 }\end{array}$ & - & - & 289 & 2.03 & 226 \\
\hline $\begin{array}{l}\text { SB-1SJ- } \\
\text { ST-200 }\end{array}$ & - & - & 290 & 2.38 & 235 \\
\hline $\begin{array}{l}\text { SB-1SJ- } \\
0.33 \mathrm{~L}\end{array}$ & - & - & 287 & 2.52 & 225 \\
\hline $\begin{array}{l}\text { SB-1SJ- } \\
0.74 \mathrm{~L}\end{array}$ & - & - & 293 & 2.60 & 245 \\
\hline SB-1SJ-2.0 & - & - & 300 & 2.21 & 276 \\
\hline $\begin{array}{l}\text { SB-1SJ- } \\
2.3-3.6\end{array}$ & $2 \varnothing 10(2.30)$ & $5 \varnothing 8 / \mathrm{m}(3.60)$ & 318 & 5.70 & 280 \\
\hline $\begin{array}{l}\text { SB-1SJ- } \\
3.3-3.6\end{array}$ & $2 \varnothing 12(3.30)$ & $5 \varnothing 8 / \mathrm{m}(3.60)$ & 328 & 5.85 & 285 \\
\hline $\begin{array}{l}\text { SB-1SJ- } \\
5.8-3.6\end{array}$ & $2 \varnothing 16(5.80)$ & $5 \varnothing 8 / \mathrm{m}(3.60)$ & 352 & 6.10 & 290 \\
\hline $\begin{array}{l}\text { SB-1SJ- } \\
7.4-3.6\end{array}$ & $2 \varnothing 18(7.40)$ & $5 \varnothing 8 / \mathrm{m}(3.60)$ & 376 & 6.20 & 295 \\
\hline
\end{tabular}

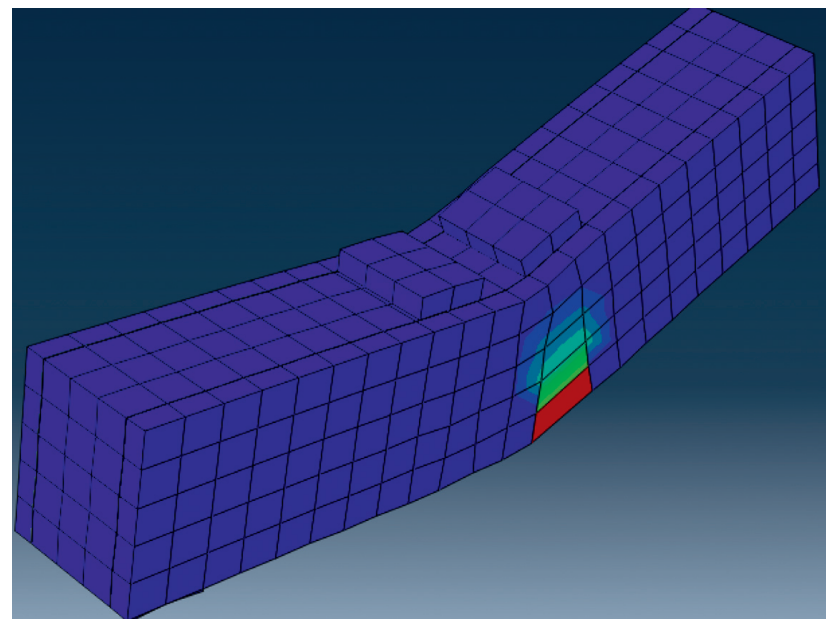

Figure 20: Flexural failure mode at failure of specimen SB-2SJ-7.4-3.6.

of specimen CT-2.0. Beam SB-3SJ-0.74L failed at $341 \mathrm{kN}$ with an increasing ratio of $19.70 \%$ compared with that of the control specimen. This finding indicated that the design engineers should strengthen the entire length of the RC beam with UHPFRC layers. This strengthening technique demonstrated the highest ultimate load with sufficient deflection.

4.3. Reinforcing UHPFRC Layers. To increase the ultimate load and ductility of the strengthened RC beams, we used UHPFRC layers with reinforcement bars (Figure 19) for external strengthening with different reinforcement ratios, as shown in Table 10.
As expected, the first group (vertically strengthened) reinforcing the UHPFRC vertical layers in the case of beam SB2SJ-2.3-3.6 increased not only the ultimate load by $14 \%$, compared with specimen SB-2SJ-2.0, but also the deflection at ultimate load by $22 \%$. Beam SB-2SJ-7.4-3.6 with the largest reinforcement ratio obtained the highest ultimate load at $516 \mathrm{kN}$, whereas specimen SB-2SJ-2.0 obtained an ultimate load of $317 \mathrm{kN}$. The use of reinforced UHPFRC layers improved not only the ultimate load and deflection at ultimate load but also the failure mode manifested as flexural cracks, as shown in Figure 20. As a result, increasing the transversal reinforcement ratio within the UHPFRC layers did not significantly improve the ultimate load capacity of the strengthened specimens. Moreover, reinforcement helped in the uniform distribution of 


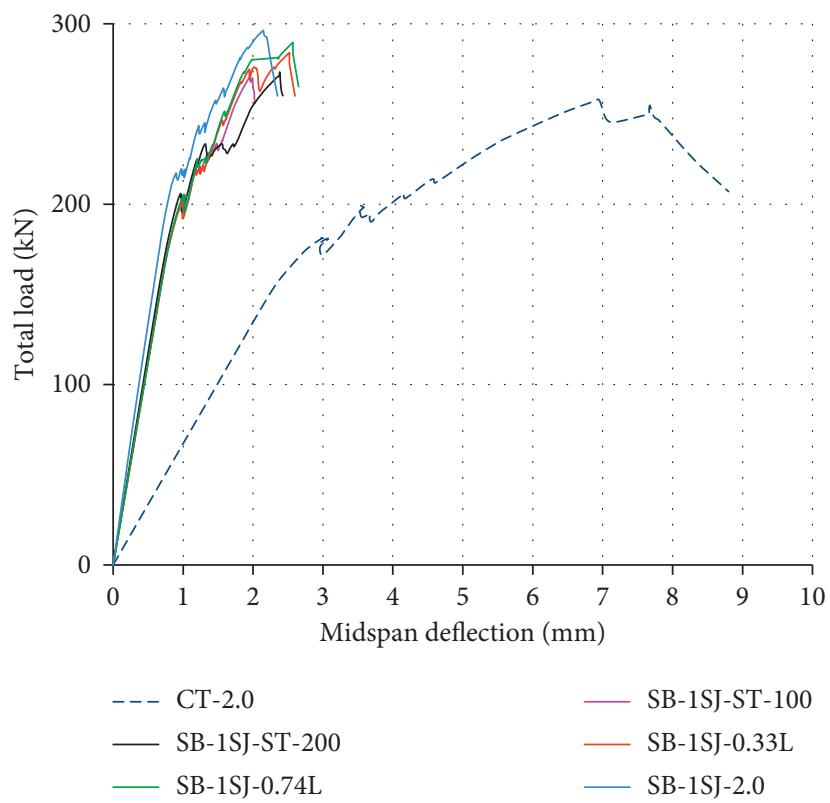

FIGURE 21: Load-deflection behaviour of the RC beams strengthened using nonreinforced UHPFRC layer.

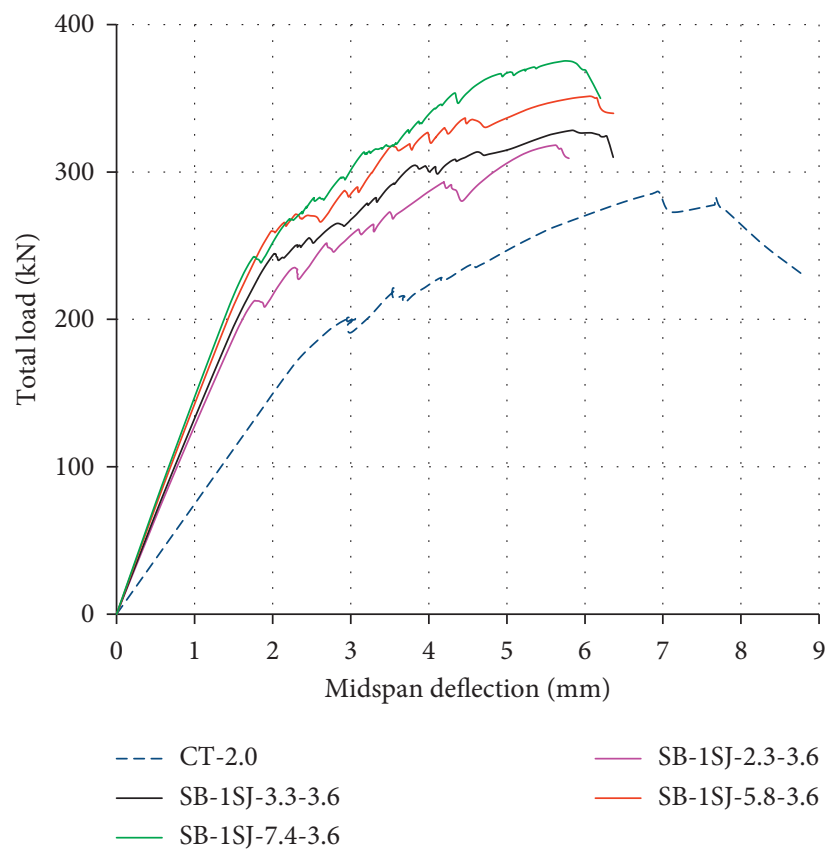

FIGURE 22: Load-deflection behaviour of the RC beams strengthened using reinforced UHPFRC layer.

stresses occurring on the surface of the strengthened RC beams and resulted in large deformations at failure.

However, specimen SB-3SJ-7.4-8.5 from the second group (strengthening vertical faces in addition to the lower face) obtained the largest ultimate load amongst all the strengthened RC specimens at $673 \mathrm{kN}$, whereas beam specimen SB-3SJ-2.0 achieved an ultimate load of $356 \mathrm{kN}$. Moreover, specimens SB3SJ-2.3-2.6, SB-3SJ-3.3-3.8, and SB-3SJ-5.8-6.7 obtained higher ultimate load at $38 \%, 58 \%$, and $80 \%$, respectively, compared with specimen SB-3SJ-2.0.
4.4. Strengthening of One Longitudinal Vertical Face. Strengthening two longitudinal vertical faces of the RC beams may not be available at all times, especially in exterior beams due to the neighbouring borders. Nine strengthened RC beams were divided into two groups. The first contained five RC beams, which were strengthened using a nonreinforced UHPFRC layer with different strengthening lengths, whereas the second group adjoined four RC beams, which were strengthened over the entire length by using a reinforced UHPFRC layer with different reinforcement ratios, as demonstrated in Table 11. Additionally, 
the RC control beam CT-2.0 was imported within the table for comparison with the strengthened RC beams. Notably, only the surface of the RC beam without the UHPFRC layer was loaded and supported to simulate the real structure case of the strengthened RC beams.

Regarding the first group, beams SB-1SJ-ST-100, SB-1SJST-200, SB-1SJ-0.33L, SB-1SJ-0.74L, and SB-1SJ-2.0 failed completely in shear (Figure 21) at a load of 289, 290, 287, 293, and $300 \mathrm{kN}$ compared with the control RC beam CT-2.0 at $285 \mathrm{kN}$. No significant increase occurred in the ultimate load but stiffness improved significantly. The use of a reinforced UHPFRC layer in the second group improved the shear response and stiffness. Beams SB-1SJ-2.3-3.6, SB-1SJ-3.3-3.6, SB1SJ-5.8-3.6, and SB-1SJ-7.4-3.6 failed at the load values of 318, 328,352 , and $376 \mathrm{kN}$, whereas the control RC beam with sufficient deflection at ultimate load obtained a load value of $285 \mathrm{kN}$, as shown in Figure 22. Consequently, if one longitudinal vertical face of the $\mathrm{RC}$ beam is strengthened, then a reinforced UHPFRC layer is used to improve the shear response.

\section{Conclusions}

This study aims to propose FEM to simulate the behaviour of RC beams strengthened in shear by using various UHPFRC systems. The results of the numerical model and a previous study in the literature are compared to check the validity of the proposed FEM. The validated FEM is used to analyse the crucial parameters related to the design of RC beams strengthened in shear with UHPFRC layers. The main conclusions of this study are summarised as follows:

(1) The shear behaviour of normal-strength RC beams and RC beams strengthened with UHPFRC layers is affected significantly by the change in the shear span-to-depth ratio. However, the effect of shear span-to-depth ratio has not been considered in current design code equations. Accordingly, design formulas are proposed for the estimation of shear strength of normal-strength $\mathrm{RC}$ beams and RC beams strengthened with UHPFRC considering the effect of the shear span-to-depth ratio.

(2) When the UHPFRC strengthening length is changed, the highest ultimate load is obtained by strengthening the entire length of RC beams. The obtained ultimate load can be increased significantly by reinforcing the strengthening UHPFRC layers. Specimen SB-2SJ-7.45.7 failed at $511 \mathrm{kN}$ compared with $317 \mathrm{kN}$ in case of SB2SJ-2.0 with sufficient ductility. However, the ultimate load of specimen SB-3SJ-7.4-8.5 was equal to $673 \mathrm{kN}$ versus $356 \mathrm{kN}$ for specimen SB-3SJ-2.0, which was strengthened using nonreinforced UHPFRC layers.

(3) Strengthening RC beams with one longitudinal vertical face must be executed using a reinforced UHPFRC layer to improve the shear response of the strengthened $\mathrm{RC}$ beams.

\section{Data Availability}

The data used to support the findings of this study are included in the article.

\section{Conflicts of Interest}

The authors declare that they have no conflicts of interest.

\section{References}

[1] D. Baggio, K. Soudki, and M. Noël, "Strengthening of shear critical RC beams with various FRP systems," Construction and Building Materials, vol. 66, pp. 634-644, 2014.

[2] S.-T. Kang, Y. Lee, Y.-D. Park, and J.-K. Kim, “Tensile fracture properties of an ultra high performance fiber reinforced concrete (UHPFRC) with steel fiber," Composite Structures, vol. 92, no. 1, pp. 61-71, 2010.

[3] Y. Yoo, H. O. Shin, J. M. Yang, and Y. S. Yoon, "Material and bond properties of ultra high performance fiber reinforced concrete with micro steel fibers," Composites Part B: Engineering, vol. 58, pp. 122-133, 2013.

[4] K. Wille and A. E. Naaman, "Fracture energy of UHP-FRC under direct tensile loading," in Proceedings of Fracture Mechanics of Concrete and Concrete Structures-Recent Advances in Fracture Mechanics of Concrete, Seoul, Republic of Korea, May 2010.

[5] O. Tsioulou, A. Lampropoulos, and S. Paschalis, "Combined non-destructive testing (NDT) method for the evaluation of the mechanical characteristics of ultra high performance fibre reinforced concrete (UHPFRC)," Construction and Building Materials, vol. 131, pp. 66-77, 2017.

[6] K. Habel, M. Viviani, E. Denarié, and E. Brühwiler, "Development of the mechanical properties of an ultra-high performance fiber reinforced concrete (UHPFRC)," Cement and Concrete Research, vol. 36, no. 7, pp. 1362-1370, 2006.

[7] S. D. P. Benson and B. L. Karihaloo, "CARDIFRC ${ }^{\circledR}$ - development and mechanical properties. Part III: uniaxial tensile response and other mechanical properties," Magazine of Concrete Research, vol. 57, no. 8, pp. 433-443, 2005.

[8] S. Paschalis and A. Lampropoulos, "Size effect on the flexural performance of UHPFRC, " in Proceedings of the 7th HPFRCC Conference, Stuttgart, Germany, June 2015.

[9] D. Nicolaides, A. Kanellopoulos, M. Petrou, P. Savva, and A. Mina, "Development of a new ultra high performance fibre reinforced cementitious composite (UHPFRCC) for impact and blast protection of structures," Construction and Building Materials, vol. 95, pp. 667-674, 2015.

[10] K. Habel, E. Denarié, and E. Bruhwiler, "Experimental investigation of composite ultra-high performance fiber-reinforced concrete and conventional concrete members," $A C I$ Structural Journal, vol. 104, pp. 10-20, 2007.

[11] G. Martinola, A. Meda, G. A. Plizzari, and Z. Rinaldi, "Strengthening and repair of RC beams with fiber reinforced concrete," Cement and Concrete Composites, vol. 32, no. 9, pp. 731-739, 2010.

[12] P. R. Prem, A. Ramachandra Murthy, G. Ramesh, B. H. Bharatkumar, and N. R. Iyer, "Flexural behaviour of damaged RC beams strengthened with ultra high performance concrete," Advances in Structural Engineering, vol. 3, pp. 2057-2069, 2015.

[13] F. J. Alaee and B. L. Karihaloo, "Retrofitting of reinforced concrete beams with CARDIFRC," Journal of Composites for Construction, vol. 7, no. 3, pp. 174-186, 2003.

[14] T. Noshiravani and E. Brühwiler, "Experimental investigation on reinforced ultrahigh performance fiber-reinforced concrete composite beams subjected to combined bending and shear," ACI Structural Journal, vol. 110, pp. 251-262, 2013. 
[15] M. A. Al-Osta, M. N. Isa, M. H. Baluch, and M. K. Rahman, "Flexural behavior of reinforced concrete beams strengthened with ultra-high performance fiber reinforced concrete," Construction and Building Materials, vol. 134, pp. 279-296, 2017.

[16] B. A. Tayeh, Z. M. EL dada, S. Shihada, and M. O. Yusuf, "Pullout behavior of post installed rebar connections using chemical adhesives and cement based binders," Journal of King Saud University-Engineering Sciences, vol. 31, no. 4, pp. 332-339, 2019.

[17] A. P. Lampropoulos, S. A. Paschalis, O. T. Tsioulou, and S. E. Dritsos, "Strengthening of reinforced concrete beams using ultra high performance fibre reinforced concrete (UHPFRC)," Engineering Structures, vol. 106, pp. 370-384, 2016.

[18] G. Ruano, F. Isla, D. Sfer, and B. Luccioni, "Numerical modeling of reinforced concrete beams repaired and strengthened with SFRC," Engineering Structures, vol. 86, pp. 168-181, 2015.

[19] C. E. Chalioris, G. E. Thermou, and S. J. Pantazopoulou, "Behaviour of rehabilitated RC beams with self-compacting concrete jacketing-analytical model and test results," Construction and Building Materials, vol. 55, pp. 257-273, 2014.

[20] L. Hussein and L. Amleh, "Structural behavior of ultra-high performance fiber reinforced concrete-normal strength concrete or high strength concrete composite members," Construction and Building Materials, vol. 93, pp. 1105-1116, 2015.

[21] A. A. Bahraq, M. A. Al-Osta, A. Shamsad, M. A. Mesfer, S. A. Othman, and M. K. Rahman, "Experimental and numerical investigation of shear behavior of RC beams strengthened by ultra-high performance concrete," International Journal of Concrete Structures and Materials, vol. 13, pp. 1-19, 2019.

[22] S. Mostosi, A. Meda, P. Riva, and S. Maringoni, "Shear strengthening of RC beams with high performance jacket," in Proceedings of the Fib Symposium in Prague. Concrete Engineering for Excellence and Efficiency, Prague, Czech Republic, September 2011.

[23] M. A. Sakr, A. A. Sleemah, T. M. Khalifa, and W. N. Mansour, "Shear strengthening of reinforced concrete beams using prefabricated ultra-high performance fiber reinforced concrete plates: experimental and numerical investigation," Structural Concrete, vol. 20, no. 3, pp. 1137-1153, 2019.

[24] T. J. Mohammed, B. H. Abu Bakar, and N. Muhamad Bunnori, "Torsional improvement of reinforced concrete beams using ultra high-performance fiber reinforced concrete (UHPFC) jackets-experimental study," Construction and Building Materials, vol. 106, pp. 533-542, 2016.

[25] K. Hibbitt and I. Sorensen, ABAQUS Theory Manual, User Manual and Example Manual, Simulia, Providence, RI, USA, 2000.

[26] V. Birtel and P. Mark, "Parameterised finite element modelling of RC beam shear failure," in Proceedings of the ABAQUS Users' Conference 2007, Boston, MA, USA, May 2006.

[27] B. A. Tayeh, B. H. Abu Bakar, M. A. Megat Johari, and Y. L. Voo, "Mechanical and permeability properties of the interface between normal concrete substrate and ultra high performance fiber concrete overlay," Construction and Building Materials, vol. 36, pp. 538-548, 2012.

[28] B. A. Tayeh, B. H. Abu Bakar, and M. A. Megat Johari, "Characterization of the interfacial bond between old concrete substrate and ultra high performance fiber concrete repair composite," Materials and Structures, vol. 46, no. 5, pp. 743-753, 2013.

[29] B. A. Tayeh, B. H. A. Bakar, M. A. M. Johari, and M. M. Ratnam, "The relationship between substrate roughness parameters and bond strength of ultra high-performance fiber concrete," Journal of Adhesion Science and Technology, vol. 27, no. 16, pp. 1790-1810, 2013.

[30] B. A. Tayeh, B. H. A. Bakar, M. A. M. Johari, and Y. L. Voo, "Evaluation of bond strength between normal concrete substrate and ultra high performance fiber concrete as a repair material," Procedia Engineering, vol. 54, pp. 554-563, 2013.

[31] B. A. Tayeh, B. H. A. Bakar, M. A. M. Johari, and Y. L. Voo, "Utilization of ultra-high performance fibre concrete (UHPFC) for rehabilitation-a review," Procedia Engineering, vol. 54, pp. 525-538, 2013.

[32] B. A. Tayeh, M. A. Naja, S. Shihada, and M. Arafa, "Repairing and strengthening of damaged RC columns using thin concrete jacketing," Advances in Civil Engineering, vol. 2019, Article ID 2987412, 16 pages, 2019.

[33] T. C. Zsutty, "Shear strength prediction for separate categories of simple beam tests," ACI Journal, vol. 68, pp. 138-143, 1971.

[34] Z. P. Bazant and J. K. Kim, "Size effect in shear failure of longitudinally reinforced beams," ACI Journal, vol. 81, pp. 456-466, 1984.

[35] J. Niwa, K. Yamada, K. Yokozawa, and H. Okamura, "Revaluation of the equation for shear strength of reinforced concrete beams without web reinforcement," Translation from Proceedings of the JSCE, vol. 372, pp. 65-84, 1986.

[36] W. Li and C. K. Y. Leung, "Effect of shear span-depth ratio on mechanical performance of RC beams strengthened in shear with U-wrapping FRP strips," Composite Structures, vol. 177, pp. 141-157, 2017.

[37] K. C. Rajendra, K. Shailendra, and M. C. Raob, "Effect of shear-span/depth ratio on cohesive crack and double-K fracture parameters of concrete," Advances in Concrete Construction, vol. 2, no. 3, pp. 229-247, 2014.

[38] H. Kim, M. S. Kim, M. J. Ko, and Y. H. Lee, "Shear behavior of concrete beams reinforced with GFRP shear reinforcement," International Journal of Polymer Science, vol. 2015, Article ID 213583, 8 pages, 2015.

[39] M. K. Svetlana and D. S. Biljana, "Bending resistance of composite sections with nonductile shear connectors and partial shear connection," Advances in Civil Engineering, vol. 2018, Article ID 5350315, 14 pages, 2018.

[40] European Committee for Standardization, EN 1992-1-1: Eurocode2: Design of Concrete Structures-Part 1-1:General Rules and Rules for Buildings, European Committee for Standardization, Brussels, Belgium, 2004.

[41] ACI (American Concrete Institute), Building Code Requirements for Reinforced Concrete (ACI 318-05) and Commentary (ACI 318R-05), American Concrete Institute, Detroit, MI, USA, 2005.

[42] O. B. Olalusi and C. Viljoen, "Assessment of simplified and advanced models for shear resistance prediction of stirrupreinforced concrete beams," Engineering Structures, vol. 186, pp. 96-109, 2019.

[43] M. Holický, J. V. Retief, and J. A. Wium, "Partial factors for selected reinforced concrete members: background to a revision of SANS 10100-1," SAICE Journal, vol. 52, pp. 36-44, 2010. 